$$
\text { FL- } 0084
$$

\title{
Simulated Effects of Projected Ground-Water Withdrawals in the Floridan Aquifer System, Greater Orlando Metropolitan Area, East-Central Florida
}

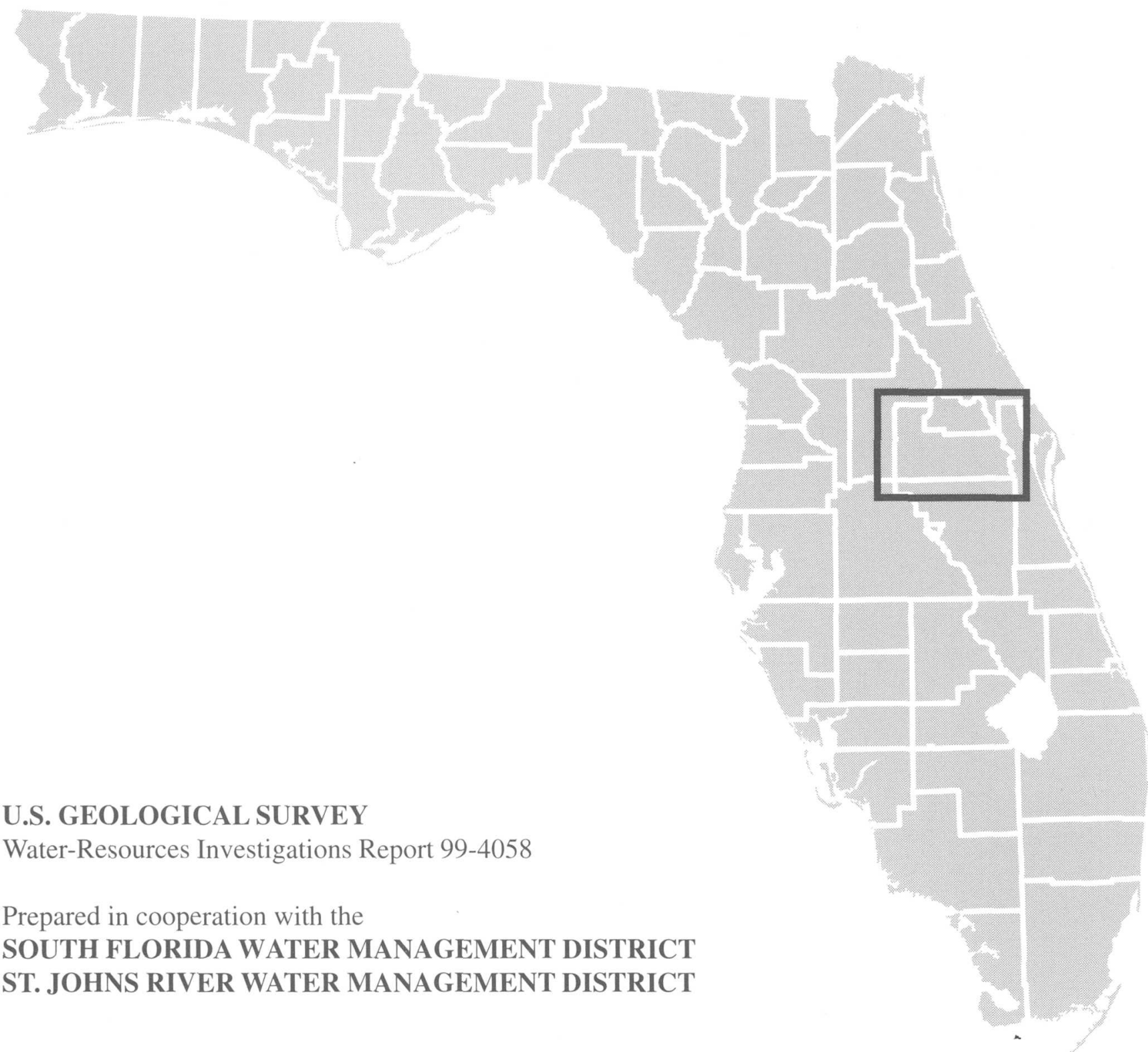


7

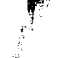

$$
\begin{aligned}
& \text { a } \\
& .
\end{aligned}
$$

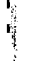




\section{Simulated Effects of Projected Ground- Water Withdrawals in the Floridan Aquifer System, Greater Orlando Metropolitan Area, East-Central Florida}

By Louis C. Murray, Jr. and Keith J. Halford

\section{U.S. GEOLOGICAL SURVEY}

Water-Resources Investigations Report 99-4058

Prepared in cooperation with the

South Florida Water Management District

St. Johns River Water Management District

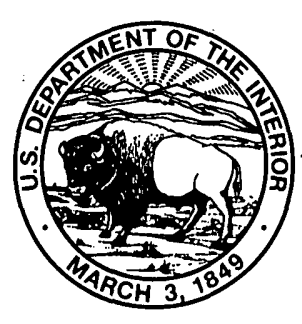




\title{
U.S. DEPARTMENT OF THE INTERIOR BRUCE BABBITT, Secretary
}

\author{
U.S. GEOLOGICAL SURVEY \\ Charles G. Groat, Director
}

The use of firm, trade, and brand names in this report is for identification purposes only and does not constitute endorsement by the U.S. Geological Survey.

For additional information write to:

District Chief

U.S. Geological Survey, WRD

Suite 3015

227 North Bronough Street

Tallahassee, FL 32301
Copies of this report can be purchased from:

U.S. Geological Survey

Branch of Information Services

Box 25286

Denver Federal Center

Denver, CO 80225-0286 


\section{CONTENTS}

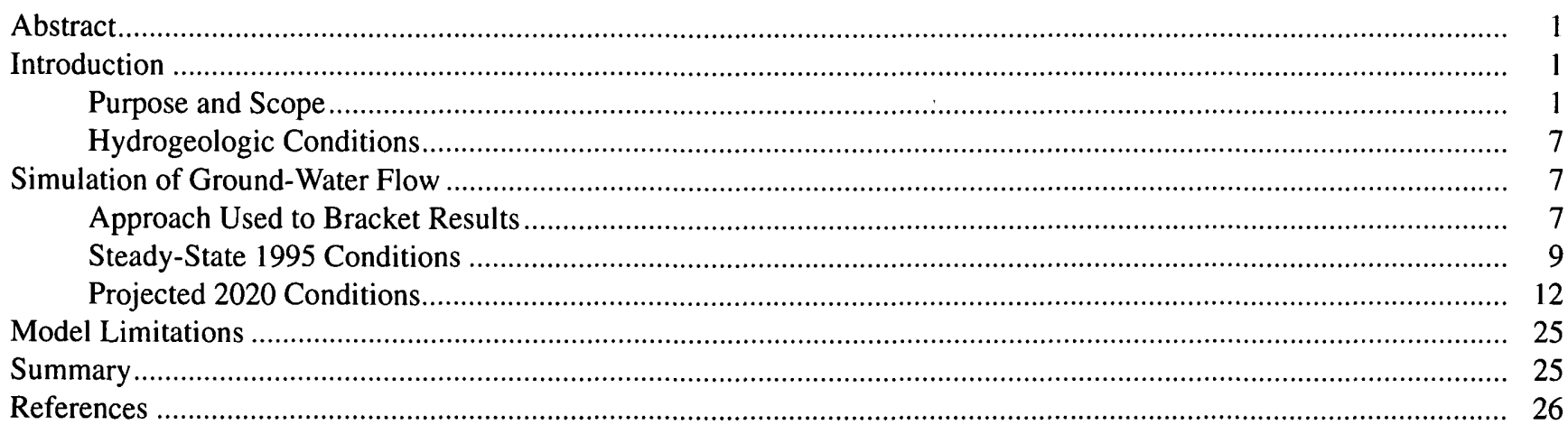

\section{FIGURES}

1-5. Maps showing:

1. Location of study area ................................................................................................................

2. Locations and rates of pumpage from the Upper Floridan aquifer, average 1995 conditions...................... 3

3. Locations and rates of pumpage from the Lower Floridan aquifer, average 1995 conditions ...................... 4

4. Locations and rates of pumpage from the Upper Floridan aquifer, projected 2020 conditions ..................... 5

5. Locations and rates of pumpage from the Lower Floridan aquifer, projected 2020 conditions..................... 6

6. Diagram showing geologic units, hydrogeologic units, and equivalent layers and boundary conditions used in the ground-water flow model

7. Map showing simulated and observed potentiometric surfaces of the Upper Floridan aquifer, average 1995 conditions

8. Map showing simulated potentiometric surface of the Lower Floridan aquifer, average 1995 conditions............ 11

9. Diagram showing simulated hydrologic budget for average 1995 steady-state conditions............................... 12

10-19. Maps showing:

10. Simulated potentiometric surface of the Upper Floridan aquifer, wet 2020 steady-state conditions .............. 14

11. Simulated potentiometric surface of the Upper Floridan aquifer, dry 2020 steady-state conditions .............. 15

12. Simulated drawdown in the Upper Floridan aquifer from average 1995 to wet 2020 steady-state conditions

13. Simulated drawdown in the Upper Floridan aquifer from average 1995 to dry 2020 steady-state conditions.

14. Simulated potentiometric surface of the Lower Floridan aquifer, wet 2020 steady-state conditions .............. 18

15. Simulated potentiometric surface of the Lower Floridan aquifer, dry 2020 steady-state conditions.............. 19

16. Simulated drawdown in the Lower Floridan aquifer from average 1995 to wet 2020 steady-state conditions

17. Simulated drawdown in the Lower Floridan aquifer from average 1995 to dry 2020 steady-state conditions

18. Difference in simulated drawdown in the Upper Floridan aquifer from wet 2020 conditions to dry 2020 conditions

19. Difference in simulated drawdown in the Lower Floridan aquifer from wet 2020 conditions to dry 2020 conditions

20. Diagram showing simulated hydrologic budgets for projected steady-state 2020 wet and dry conditions............ 24

\section{TABLE}

1. Measured and simulated discharge from Upper Floridan aquifer springs for average 1995 conditions and projected 2020 steady-state wet and dry conditions 


\section{CONVERSION FACTORS, VERTICAL DATUM, ABBREVIATIONS AND ACRONYMS}

\begin{tabular}{rcl}
\hline Multiply & By & To obtain \\
\hline & Length & \\
inch (in) & 2.54 & centimeter \\
foot (ft) & 0.3048 & meter \\
& Flow Rate & \\
cubic foot per second $\left(\mathrm{ft}^{3} / \mathrm{s}\right)$ & 0.02832 & cubic meter per second \\
cubic foot per second $\left(\mathrm{ft}^{3} / \mathrm{s}\right)$ & 0.6463 & million gallons per day \\
million gallons per day $(\mathrm{Mgal} / \mathrm{d})$ & 0.04381 & cubic meter per second \\
\hline
\end{tabular}

Temperature in degrees Fahrenheit $\left({ }^{\circ} \mathrm{F}\right)$ may be converted to degrees Celsius $\left({ }^{\circ} \mathrm{C}\right)$ as follows: ${ }^{\circ} \mathrm{C}=\left({ }^{\circ} \mathrm{F}-32\right) / 1.8$.

Sea level: In this report, "sea level" refers to the National Geodetic Vertical Datum of 1929 (NGVD of 1929)--a geodetic datum derived from a general adjustment of the first-order level nets of both the United States and Canada, formerly called Sea Level Datum of 1929.

Acronyms and additional abbreviations used in report:

$\begin{array}{ll}\text { GHB } & \text { General-head boundary } \\ \text { MGD } & \text { Million gallons per day } \\ \text { MODFLOW } & \text { Modular Finite-Difference Model } \\ \text { RASA } & \text { Regional Aquifer Systems Analysis } \\ \text { SJRWMD } & \text { St. Johns River Water Management District } \\ \text { SFWMD } & \text { South Florida Water Management District } \\ \text { USGS } & \text { U.S. Geological Survey }\end{array}$




\title{
Simulated Effects of Projected Ground-Water Withdrawals in the Floridan Aquifer System, Greater Orlando Metropolitan Area, East-Central Florida
}

\author{
By Louis C. Murray, Jr. and Keith J. Halford
}

\section{Abstract}

Ground-water levels in the Floridan aquifer system within the greater Orlando metropolitan area are expected to decline because of a projected increase in the average pumpage rate from 410 million gallons per day in 1995 to 576 million gallons per day in 2020. The potential decline in ground-water levels and spring discharge within the area was investigated with a calibrated, steadystate, ground-water flow model. A wetter-thanaverage condition scenario and a drought-condition scenario were simulated to bracket the range of water-levels and springflow that may occur in 2020 under average rainfall conditions. Pumpage used to represent the drought-condition scenario totaled 865 million gallons per day, about 50 percent greater than the projected average pumpage rate in 2020 .

Relative to average 1995 steady-state conditions, drawdowns simulated in the Upper Floridan aquifer exceeded 10 and 25 feet for wet and dry conditions, respectively, in parts of central and southwest Orange County and in north Osceola County. In Seminole County, drawdowns of up to 20 feet were simulated for dry conditions, compared with 5 to 10 feet simulated for wet conditions. Computed springflow was reduced by 10 percent for wet conditions and by 38 percent for dry conditions, with the largest reductions (28 and 76 percent) occurring at the Sanlando Springs group. In the Lower Floridan aquifer, drawdowns simulated in southwest Orange County exceeded 20 and 40 feet for wet and dry conditions, respectively.

\section{INTRODUCTION}

The greater Orlando metropolitan area, hereafter called the study area, encompasses about 2,500 square miles in east-central Florida and includes all of Orange and Seminole Counties, and parts of adjacent Lake, Volusia, Brevard, Osceola and Polk Counties (fig. 1). Virtually all of the water used for municipal, industrial, and agricultural supplies in the study area is obtained from the underlying Floridan aquifer system. Groundwater withdrawals from this system are permitted by the St. Johns River and South Florida Water Management Districts (SJRWMD and SFWMD), the two State agencies largely responsible for managing the development of the resource within east-central Florida.

The U.S. Geological Survey (USGS) has described the hydrogeologic and water-quality conditions in the study area (Murray and Halford, 1996). That study included a numerical model of ground-water flow (hereafter called the Metro model) that was constructed and used to evaluate the potential effects of projected groundwater withdrawals in the year 2010 on Upper and Lower Floridan aquifer heads and Upper Floridan aquifer springflow. In 1997, the water management districts requested that the USGS use the Metro model to simulate the potential effects of projected 2020 pumpage on water levels and spring discharge in the Floridan aquifer system.

\section{Purpose and Scope}

This report describes the results of a two-year cooperative study to evaluate the potential effects of projected ground-water withdrawals in the year 2020 on the Floridan aquifer system. These effects are defined in terms of simulated drawdown, relative to 1995 conditions, of water levels in the Upper and Lower Floridan aquifers, as well as reductions in the discharge from 15 Upper Floridan aquifer springs. 


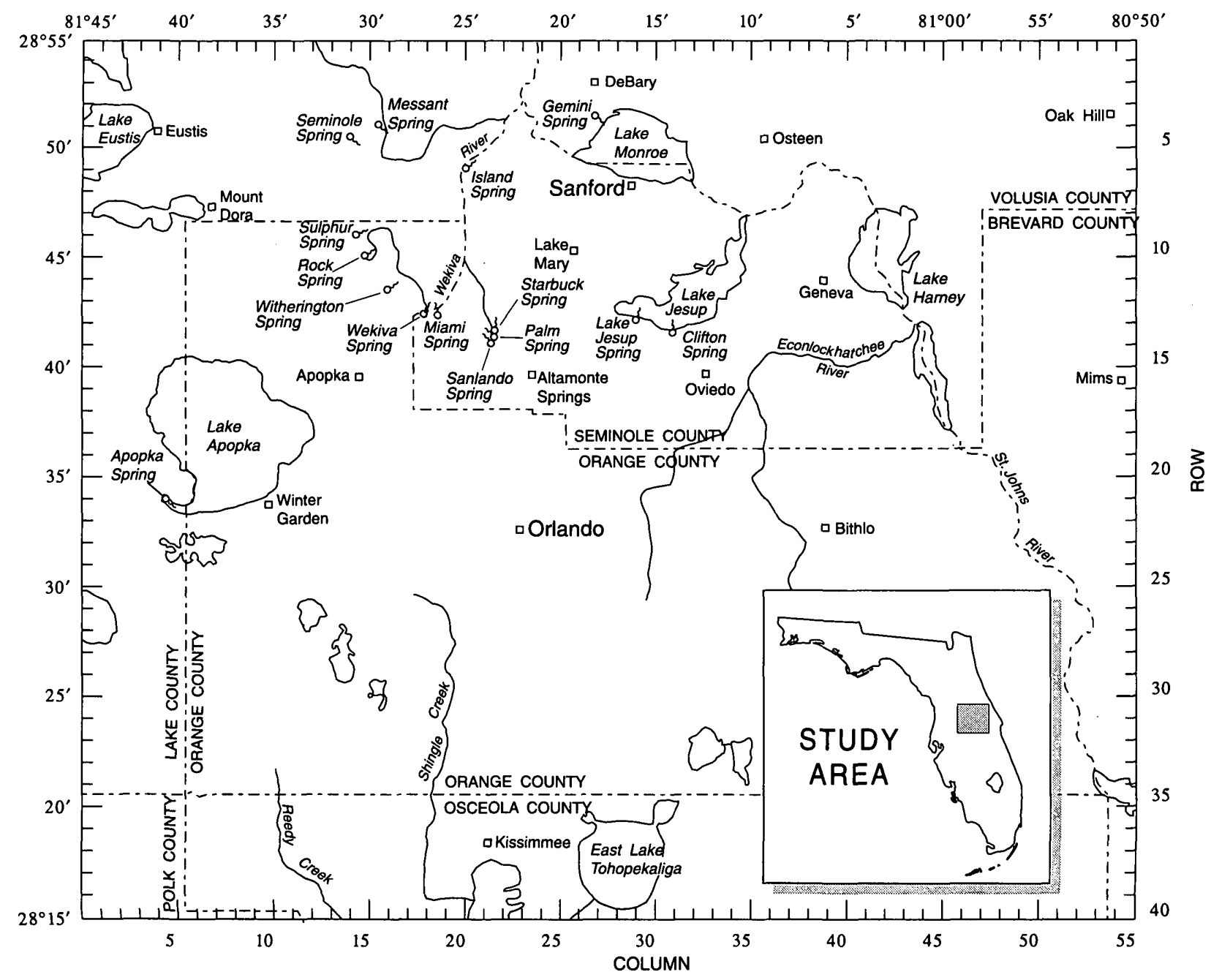

Figure 1. Location of study area.

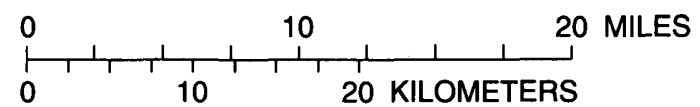

The 1995 base was selected to reflect current conditions and is suitable as a comparative benchmark because (a) rainfall across the study area in 1995 totaled 51 inches, equal to the long-term annual average; (b) water levels were in a quasi steady-state condition (water levels fluctuated seasonally about the mean with relatively little difference between those measured at the beginning and at the end of the year); and (c) 1995 water-use data were readily available. Simulated results are bracketed to address boundary-condition limitations in the Metro model and to estimate a range of potential effects of 2020 pumpage under average rainfall conditions.

Ground-water withdrawal rates specified in the 1995 and 2020 model simulations were provided by SJRWMD and SFWMD and are based largely on population projections. Average withdrawals in 1995 totaled 410 million gallons per day (Mgal/d), 75 percent of which was withdrawn from the Upper Floridan aquifer. The average withdrawal rate in 2020 is projected to increase to about $576 \mathrm{Mgal} / \mathrm{d}$ (891 cubic feet per second $\left.\left(\mathrm{ft}^{3} / \mathrm{s}\right)\right)$, with 65 percent of the total pumpage coming from the Upper Floridan aquifer. The projected increase is attributed solely to increases in municipal, industrial, and commercial demands.

Agricultural pumpage and discharge from abandoned flowing wells are assumed to remain constant at 1995 levels. The distributions and rates of pumpage from the Upper and Lower Floridan aquifers in 1995 are shown in figures 2 and 3, respectively. Included in these figures are withdrawal rates from a number of wells/wellfields that are scheduled to be abandoned by the year 2020. The distributions and rates of pumpage projected for the year 2020 are shown in figures 4 and 5 and include several new wellfields that will be developed to meet increased demands and to replace the abandoned wells. 


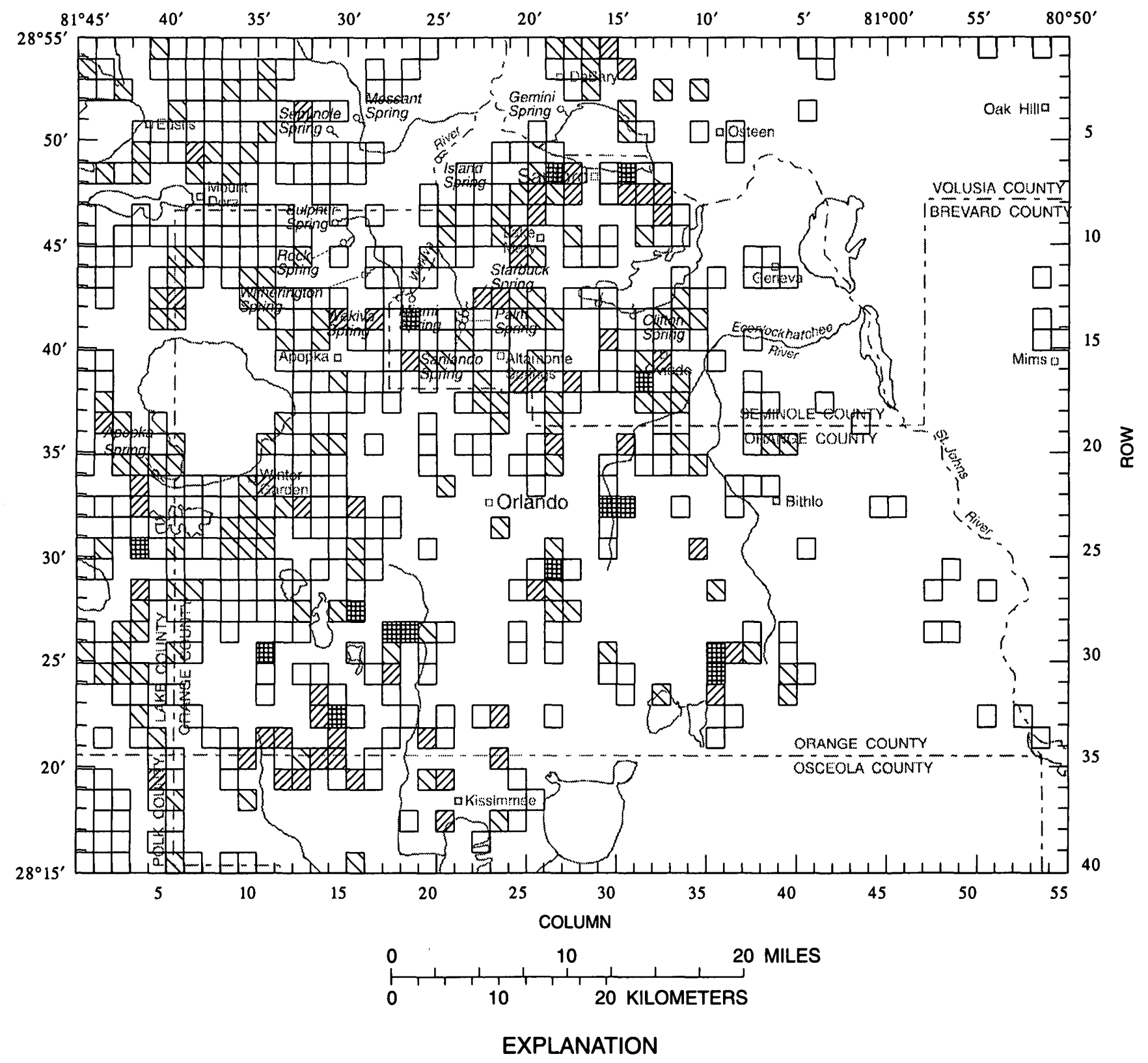

WITHDRAWAL, IN MILLIONS OF GALLONS PER DAY (Mgal/d)

Less than 0.3

$\nabla 0.3-1$

घ1-3

3-12

(Total pumpage $=305 \mathrm{Mgal} / \mathrm{d}$ )

Figure 2. Locations and rates of pumpage from the Upper Floridan aquifer, average 1995 conditions. 


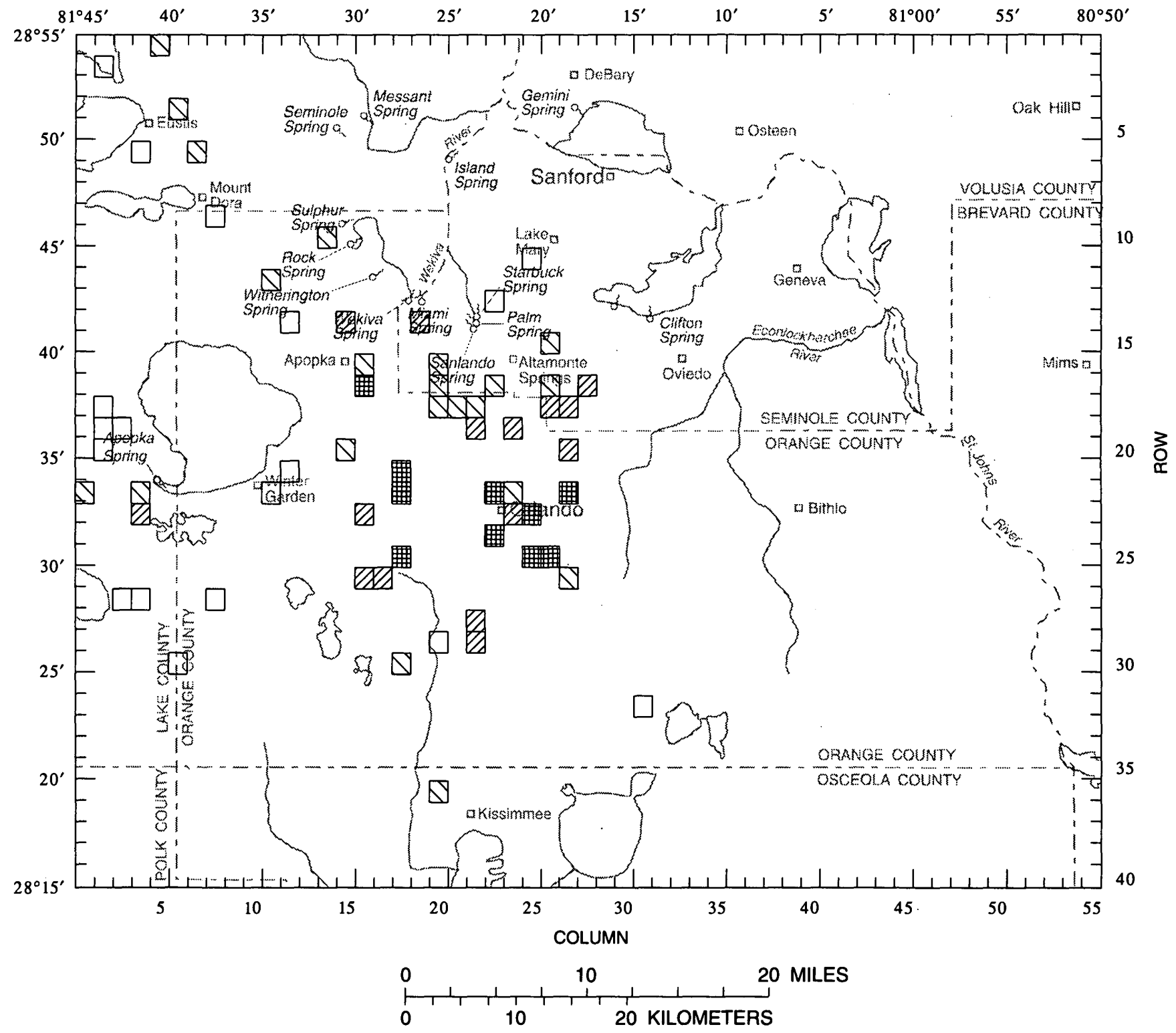

\section{EXPLANATION}

WITHDRAWAL, IN MILLIONS OF GALLONS

PER DAY (Mgal/d)

Less than 0.3

$\nabla 0.3-1$

Q1-3

成 $3-12$

(Total pumpage $=105 \mathrm{Mgal} / \mathrm{d}$ )

Figure 3. Locations and rates of pumpage from the Lower Floridan aquifer, average 1995 conditions. 


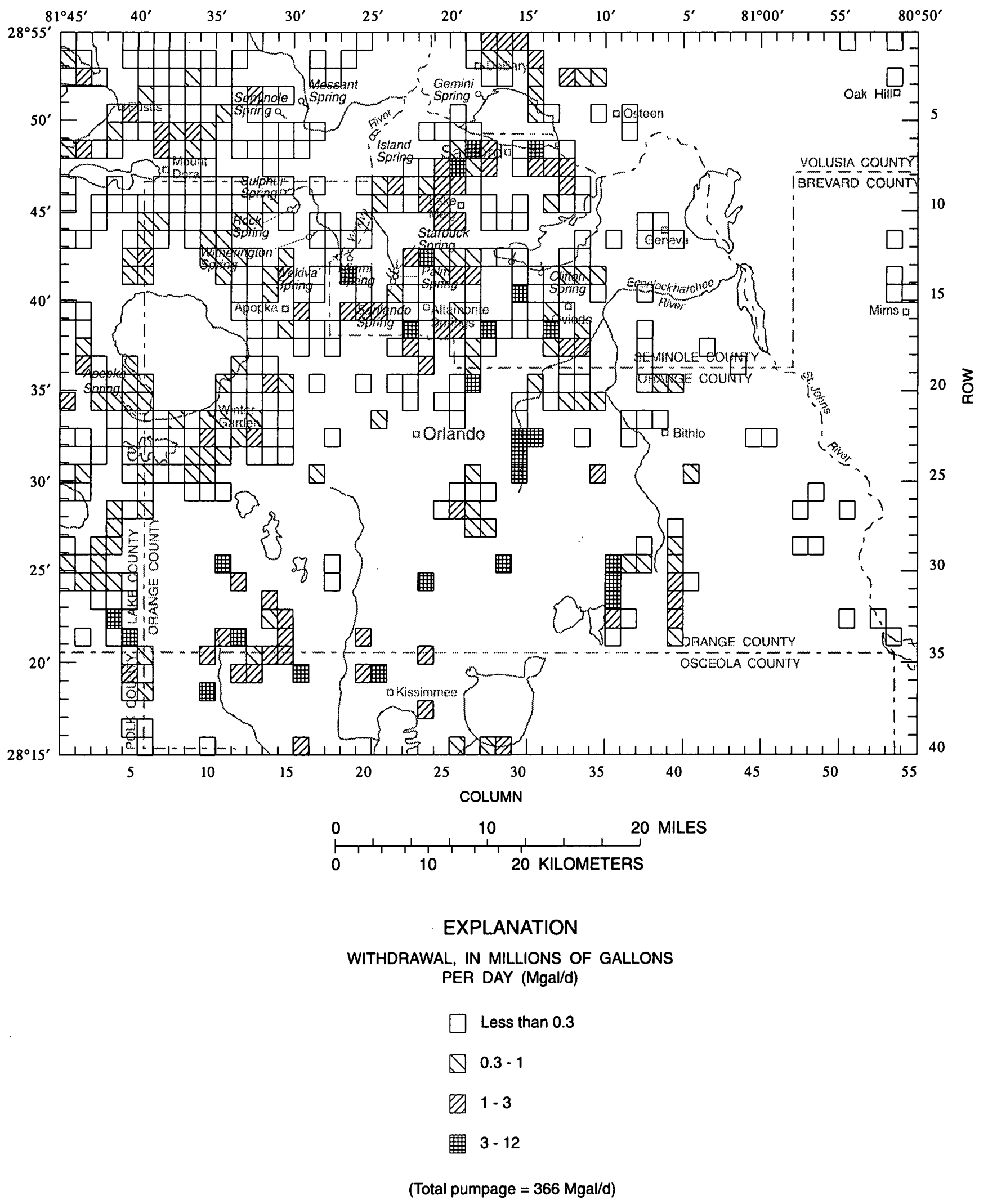

Figure 4. Locations and rates of pumpage from the Upper Floridan aquifer, projected 2020 conditions. 


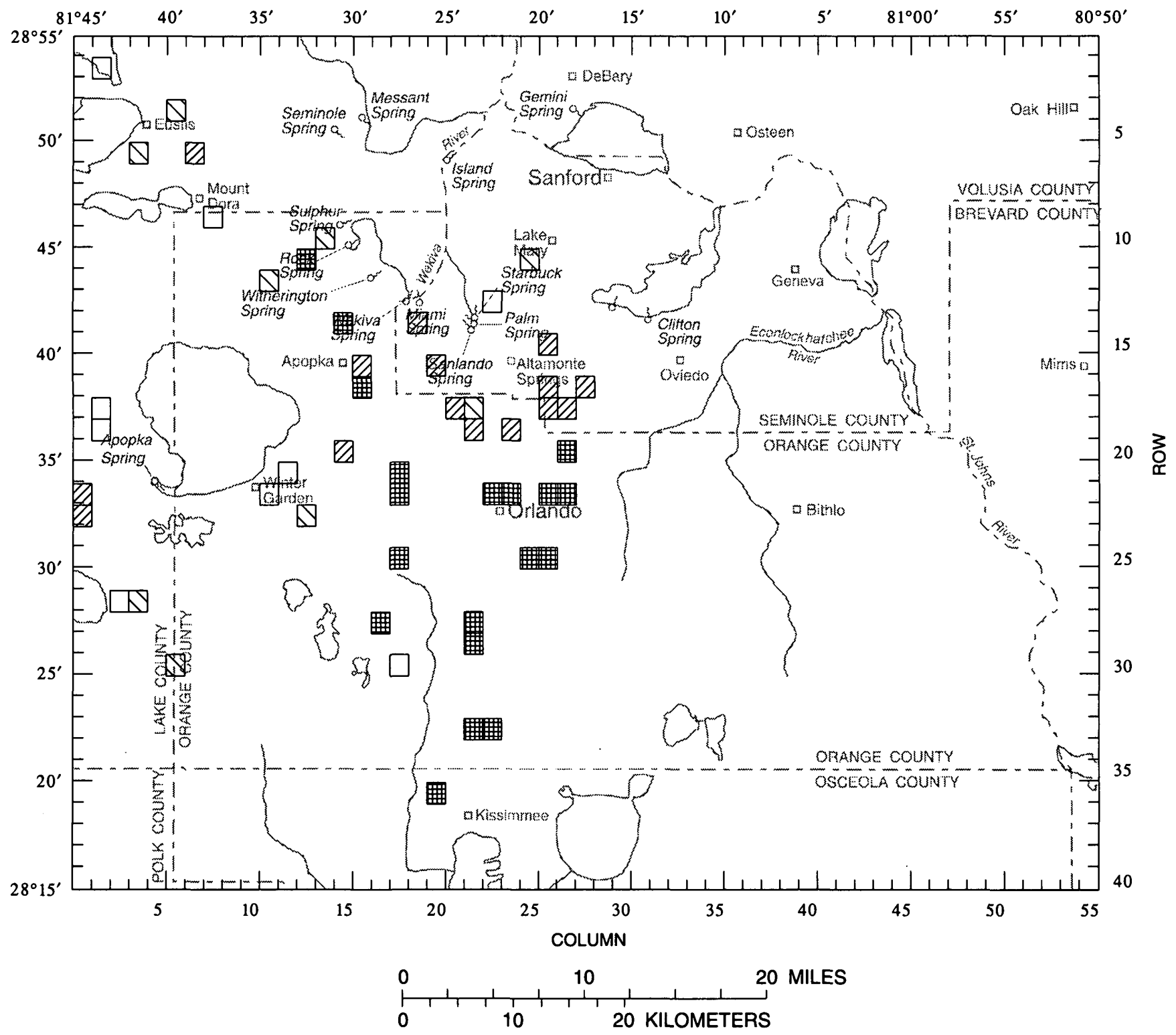

EXPLANATION

WITHDRAWAL, IN MILLIONS OF GALLONS

PER DAY (Mgal/d)

Less than 0.3

$\triangle 0.3-1$

『1-3

$3-12$

(Total pumpage $=210 \mathrm{Mgal} / \mathrm{d}$ )

Figure 5. Locations and rates of pumpage from the Lower Floridan aquifer, projected 2020 conditions. 


\section{Hydrogeologic Conditions}

The hydrogeology of the study area is characterized by a relatively thin, surficial sand aquifer underlain by the thick, highly-productive rocks of the Floridan aquifer system. The Floridan aquifer system is subdivided into two permeable zones, the Upper and Lower Floridan aquifers, separated by the less permeable middle semiconfining unit. The surficial and Upper Floridan aquifers are separated by the intermediate confining unit, an unconsolidated sequence of interbedded sands, silts, and clays of relatively low hydraulic conductivity. Hydrogeologic conditions in the greater Orlando metropolitan area are described more fully in Murray and Halford (1996).

The Upper Floridan aquifer supplies about 75 percent of the study area's ground-water demand and is recharged by the surficial aquifer system, by lateral inflow across study-area boundaries, and by recharge from Orlando drainage wells and reclaimed water. Ground water in the Floridan aquifer system generally flows from the southwest to the northeast across the study area and is discharged primarily by wells and springflow. Smaller amounts of water are discharged by diffuse upward leakage beneath the St. Johns River and as lateral outflow across study-area boundaries.

\section{SIMULATION OF GROUND-WATER FLOW}

A three-dimensional numerical model was used to quantitatively analyze ground-water flow through the Floridan aquifer system. The McDonald and Harbaugh (1988) modular finite-difference model (MODFLOW) was used to simulate flow in the Floridan aquifer system and to solve the governing equations. The model grid defines a 40-row and 55-column matrix of cells, each about one square mile in area, that is vertically discretized into three layers. The surficial aquifer system was simulated as an array of specified heads in layer 1 that was a source or sink for the Upper Floridan aquifer. The Upper and Lower Floridan aquifers are each represented by a single active layer. The intermediate and middle semiconfining units are each represented by an array of vertical conductance values. The relationship between the hydrogeologic units and equivalent layers used in the ground-water flow model is shown in figure 6 .

Boundary conditions were simulated in the same manner as described by Murray and Halford (1996).
Head-dependent flux boundaries were specified along the model perimeter, at Upper Floridan aquifer springs, and along the St. Johns River. Recharge to the Upper Floridan aquifer from drainage wells and reclaimed water was applied directly in the model with MODFLOW's Recharge package.

The Metro model was originally calibrated to 1988 steady-state and May 1990 transient conditions by comparing simulated Upper Floridan aquifer heads and springflow with observed levels (Murray and Halford, 1996). Average 1988 conditions reflected a period of slightly above average rainfall, whereas May 1990 conditions reflected the end of a prolonged drought characterized by increased ground-water withdrawals (40 percent greater in May 1990 than the average for 1988) and declines in both surficial and Upper Floridan aquifer heads and springflow. Differences observed (or estimated) in water-table and spring-pool elevations, the stage of the St. Johns River, and recharge from drainage wells between 1988 and May 1990 were all accounted for by respective MODFLOW packages.

\section{Approach Used to Bracket Results}

For predictive 2020 simulations, the constraints imposed by model boundary conditions limit the usefulness of any single set of projected results. Because the surficial aquifer system is treated as a constant head and cannot be actively simulated, the levels and configuration of the water table under steady-state 2020 conditions could not be determined by the model, nor could these levels be specified a priori. Instead, a range of potential effects was bracketed by conducting two simulations-once with fixed 1988 surficial aquifer heads and once with fixed May 1990 surficial aquifer heads. This approach assumed that, for average rainfall conditions, surficial aquifer heads in 1988 probably would be higher than actual 2020 heads because the latter may be lowered by increased ground-water withdrawals. Consequently, water levels simulated using the 1988 heads, and hereafter referred to as "wet" 2020 conditions, are probably higher than those steady-state levels that may occur in 2020.

However, the May 1990 heads reflect the peak of an extended drought and were near historic lows, and comparison of historic water-level, lake-level, and water-use data show that surficial aquifer heads are considerably more sensitive to deficit rainfall than to increases in ground-water withdrawals. Based on the severity of the 1990 drought and the responses of lake 


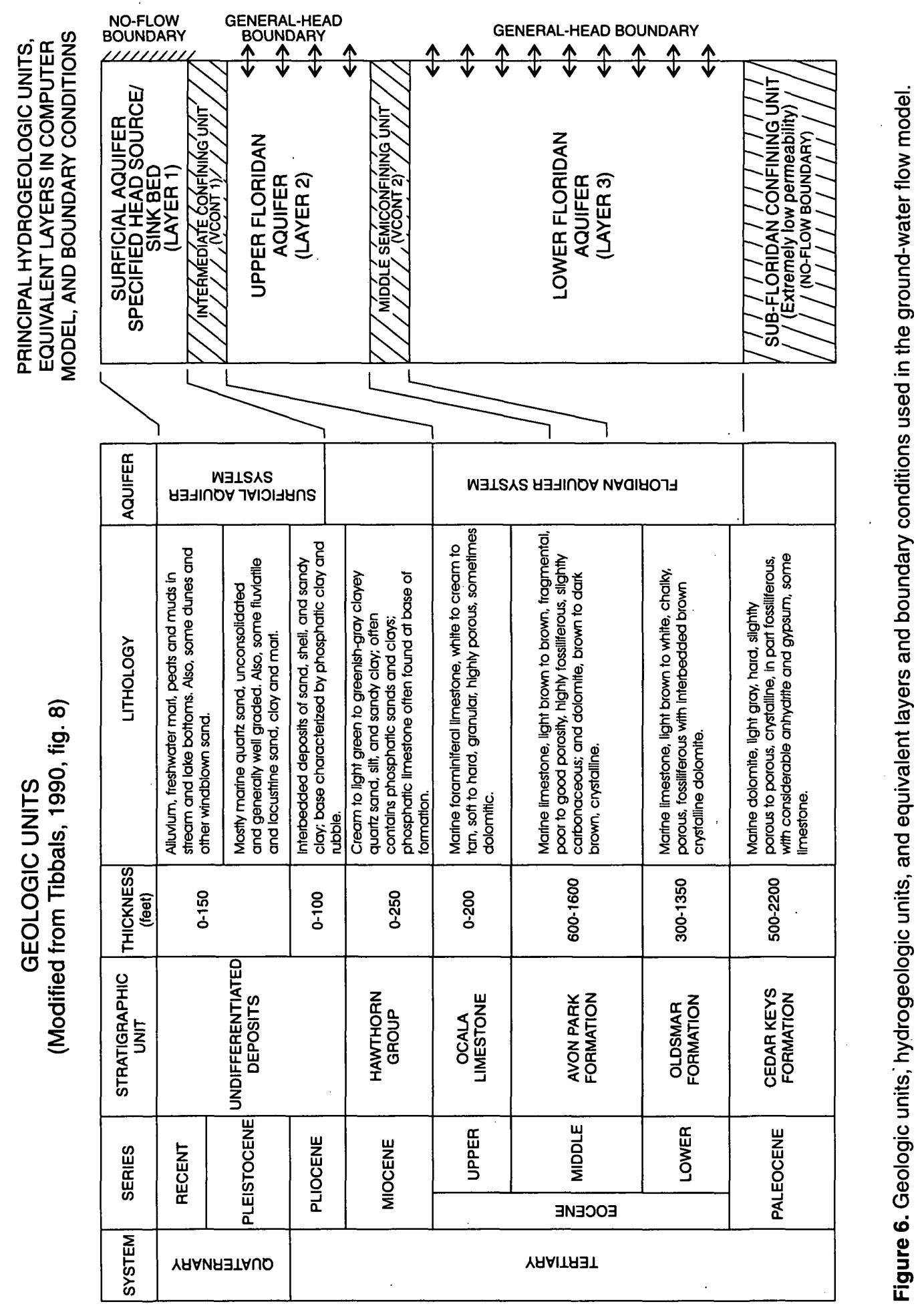


and surficial aquifer water levels to previous but comparable increases in pumpage, it is assumed that, even though increased 2020 pumpage may induce some drawdown in surficial aquifer water levels, actual steady-state 2020 surficial aquifer heads will still be higher than those observed in May 1990. Consequently, water levels simulated for 2020 "dry" conditions should be lower than those that may occur in 2020 under average rainfall conditions.

This same rationale was used in assuming that actual 2020 spring-pool heads, river heads, and drainage-well recharge rates would also fall somewhere between the fixed values specified in respective 1988 and May 1990 arrays. As a result, the water levels and springflow simulated by the model for the 2020 wet conditions (using the 1988 fixed-head and appliedrecharge arrays) and discussed in this report probably are too high, whereas the water levels and springflow simulated for the 2020 dry conditions (using May 1990 fixed-head and applied-recharge arrays) are too low.

Three simulations were performed for this study: (1) a 1995 steady-state base case; (2) a predictive 2020 simulation for wet conditions; and (3) a predictive 2020 simulation for dry conditions. Pumping rates used to simulate 2020 wet conditions were uniformly increased by a factor of 1.5 to simulate 2020 dry conditions and thus mimic the effects of increased ground-water withdrawals normally associated with droughts. The drought-multiplication factor of 1.5 was based on the percent of increase in pumpage between average 1988 rates and those observed in May 1990 (peak of the most recent and sustained drought period in central Florida).

All three simulations used the same model framework, data sets, and boundary conditions described by Murray and Halford (1996) except that specified 1988 general-head boundary (GHB) Upper Floridan and Lower Floridan aquifer heads were replaced by average 1995 heads at the lateral boundaries for the 1995 simulation. Average 1995 Upper Floridan aquifer heads were estimated from potentiometric-surface maps for May 1995 (Knowles and others, 1995) and September 1995 (O'Reilly and others, 1996). These maps are assumed to represent water levels at the end of the dry and wet seasons, respectively. Lower Floridan aquifer heads specified at the lateral boundaries were assumed to be two feet lower than respective Upper Floridan aquifers heads in recharge areas, and two feet higher than Upper Floridan aquifer heads in discharge areas (Murray and Halford, 1996).

For the 2020 simulations, projected GHB heads were estimated independently with the Regional Aquifer Systems Analysis (RASA) model (Tibbals, 1990) because simulated drawdowns intercepted the lateral boundaries, thus rendering the 1995 GHB heads too constraining for predictive purposes. The RASA model was used to estimate the change in 1995 water levels at the Metro model boundaries caused by the increase in pumpage from 1995 to 2020 for both wet and dry conditions. These changes were added to the 1995 GHB specified heads to estimate water levels for the predictive simulations. This approach was used previously by Murray and Halford (1996) to simulate the effects of projected 2010 pumpage.

\section{Steady-State 1995 Conditions}

The simulated potentiometric surfaces of the Upper Floridan and Lower Floridan aquifers for steadystate 1995 conditions are shown in figures 7 and 8 , respectively. Water-levels simulated in the Upper Floridan aquifer range from greater than 120 feet above sea level in Polk County to less than 10 feet above sea level in northeast Seminole County. Except for northeast Seminole County, simulated water levels compare reasonably well with those inferred from the observed 1995 potentiometric surface (average of published May 1995 and September 1995 potentiometric surface maps).

The largest difference (up to 12 feet) between simulated and observed water levels occurs in north Seminole County near Lake Monroe and can be attributed to a difference between USGS and SJRWMD estimates of the amount of water being discharged from abandoned flowing wells in Seminole County. Based on available data, Murray and Halford (1996) originally estimated the discharge from these wells at about 12 $\mathrm{Mgal} / \mathrm{d}\left(19 \mathrm{ft}^{3} / \mathrm{s}\right)$, whereas the SJRWMD, for the 1995 conditions defined in this study, estimated a discharge of about $34 \mathrm{Mgal} / \mathrm{d}\left(53 \mathrm{ft}^{3} / \mathrm{s}\right)$. It should be noted that any estimate of flowing-well discharge is highly speculative because the total number of wells in Seminole County is unknown and only a small fraction of the inventoried wells has been measured for discharge.

The relationship between model-simulated Upper and Lower Floridan aquifer water levels is consistent with data previously collected at Upper/ Lower Floridan aquifer monitoring-well clusters. In areas of recharge, where water from the surficial aquifer system is known to move downward into the Upper Floridan aquifer, water levels simulated in the Upper Floridan aquifer are generally higher than those simulated in the Lower Floridan aquifer. In discharge areas, where water moves upward from the Upper Floridan aquifer into the surficial aquifer system, water levels simulated in the Upper Floridan aquifer are lower than those simulated in the Lower Floridan aquifer. 


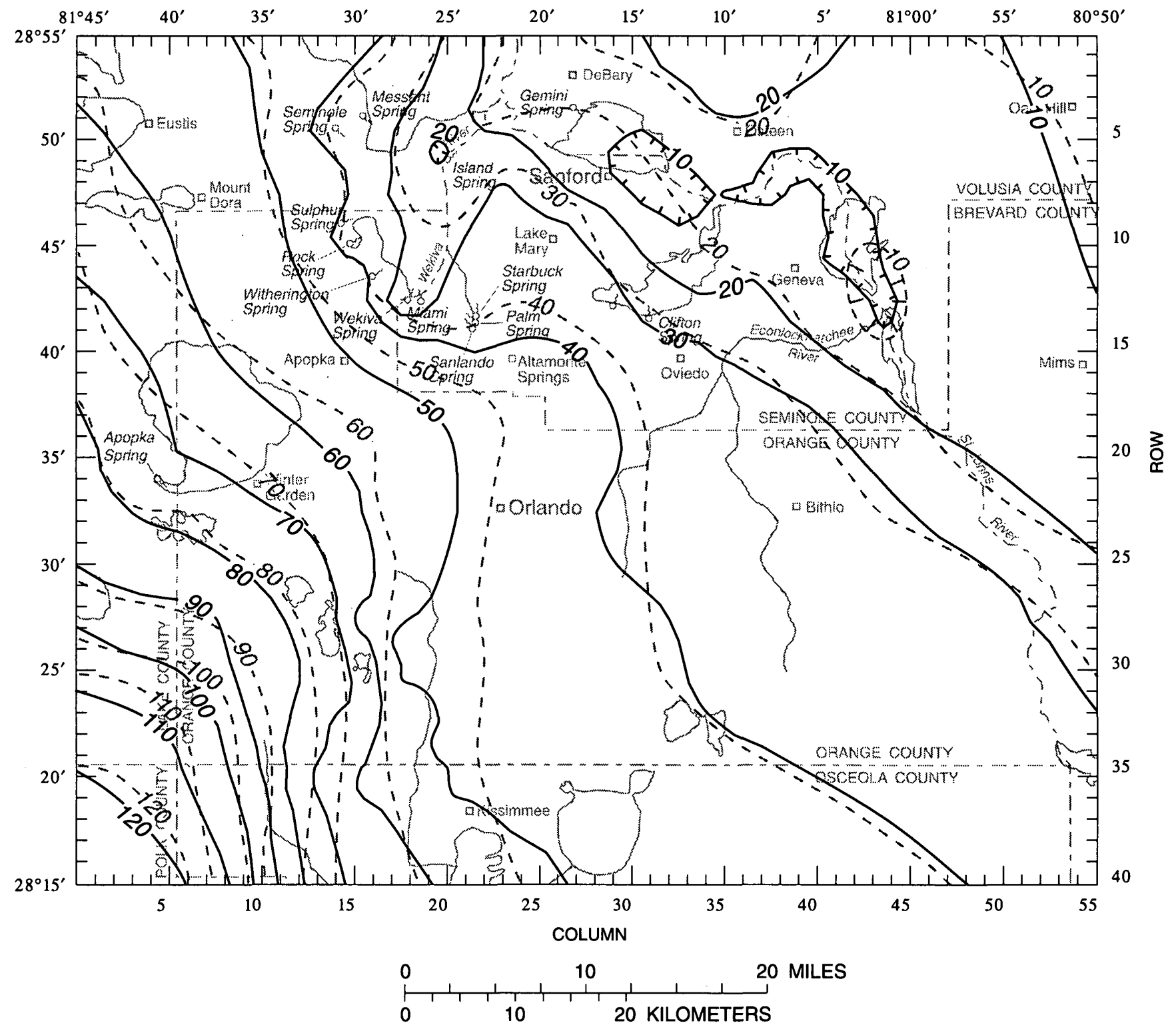

\section{EXPLANATION}

POTENTIOMETRIC CONTOUR -- Shows altitude

of potentiometric surface. Contour interval 10 feet.

Hachures indicate depressions.

Datum is sea level

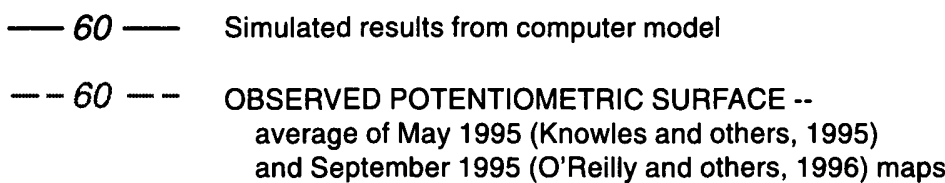

Figure 7. Simulated and observed potentiometric surfaces of the Upper Floridan aquifer, average 1995 conditions. 


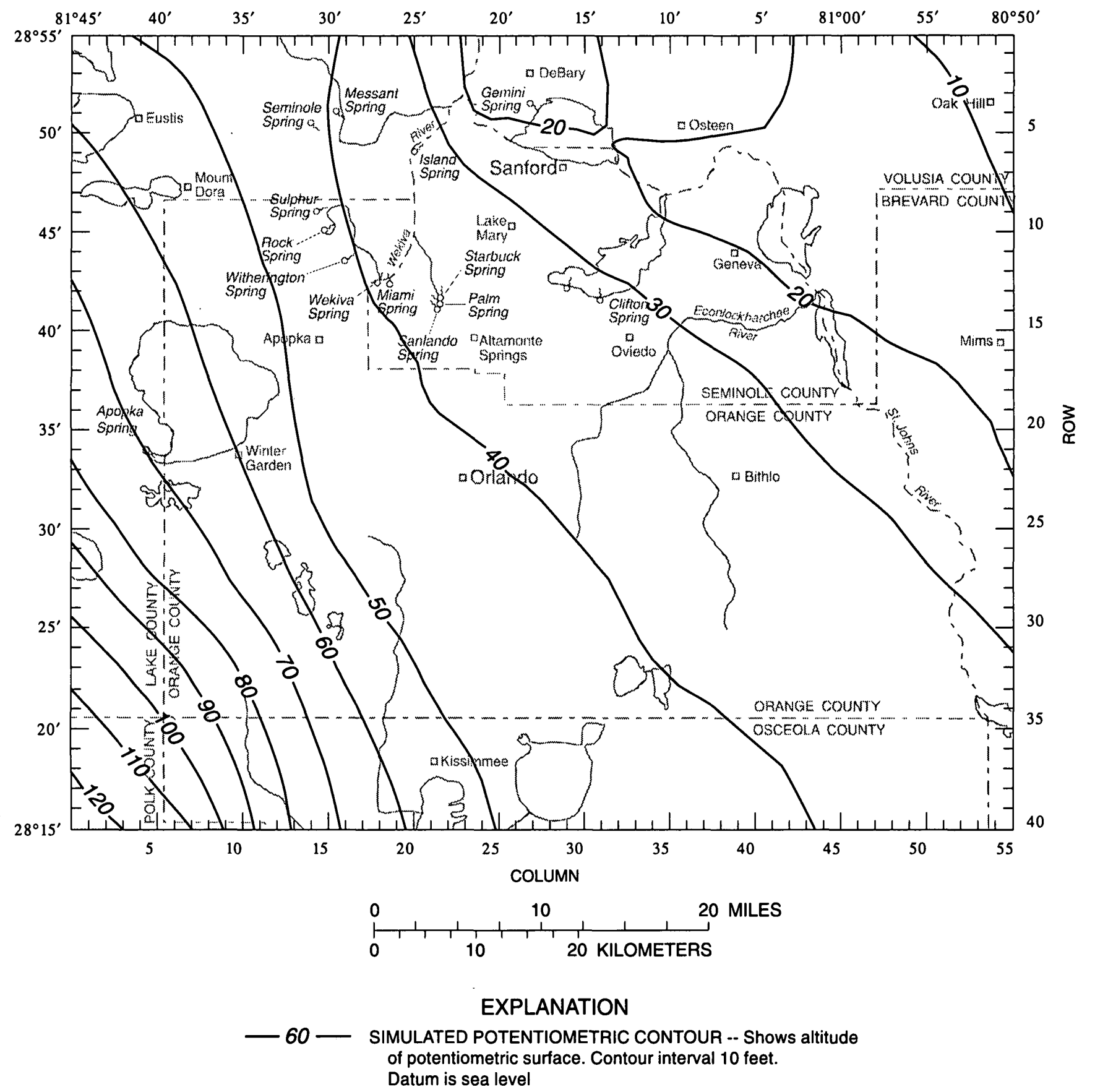

Figure 8. Simulated potentiometric surface of the Lower Floridan aquifer, average 1995 conditions. 
The rates of recharge and discharge simulated by the model to, from, and between the Upper Floridan and Lower Floridan aquifers are quantified by the water budget shown in figure 9 . The surficial aquifer system provides most of the recharge to the Floridan aquifer system $\left(851 \mathrm{ft}^{3} / \mathrm{s}\right.$ or $\left.550 \mathrm{Mgal} / \mathrm{d}\right)$, while pumping wells $\left(648 \mathrm{ft}^{3} / \mathrm{s}\right.$ or $\left.419 \mathrm{Mgal} / \mathrm{d}\right)$ and springs $\left(292 \mathrm{ft}^{3} / \mathrm{s}\right.$ or $189 \mathrm{Mgal} / \mathrm{d}$ ) are the major sources of discharge. The amount of discharge simulated at each of the 15 Upper Floridan aquifer springs is given in table 1 . The discharge measured at the larger springs in 1995 totaled $238 \mathrm{ft}^{3} / \mathrm{s}$ (154 Mgal/d), compared with $225 \mathrm{ft}^{3} / \mathrm{s}$ (145 Mgal/d) simulated by the model.

\section{Projected 2020 Conditions}

The steady-state Upper Floridan aquifer potentiometric surfaces simulated for projected 2020 wet and dry conditions are shown in figures 10 and 11 , respectively. Simulated wet-condition water levels in the
Upper Floridan aquifer (fig. 10) are considerably higher than those simulated for dry conditions (fig. 11), particularly in central Orange and north Osceola Counties where numerous high-capacity wellfields are located. Relative to 1995 conditions, drawdowns in the Upper Floridan aquifer for wet conditions range from less than 5 feet across most of the study area to greater than 10 feet over a broad area of central Orange County and at several high-capacity wellfields in southwest Orange and northwest Osceola Counties (figure 12). In one area of southwest Orange County, where several existing wellfields will be abandoned by 2020 , water levels actually will recover as much as 20 feet. For dry conditions, drawdowns exceed 25 feet in central Orange County and in north Osceola County (figure 13). In south Seminole County, drawdowns of up to 20 feet are simulated for dry conditions. Drawdowns simulated for dry conditions range between 5 and 10 feet in the southern part of Seminole County, and less than 5 feet across the rest of the county.

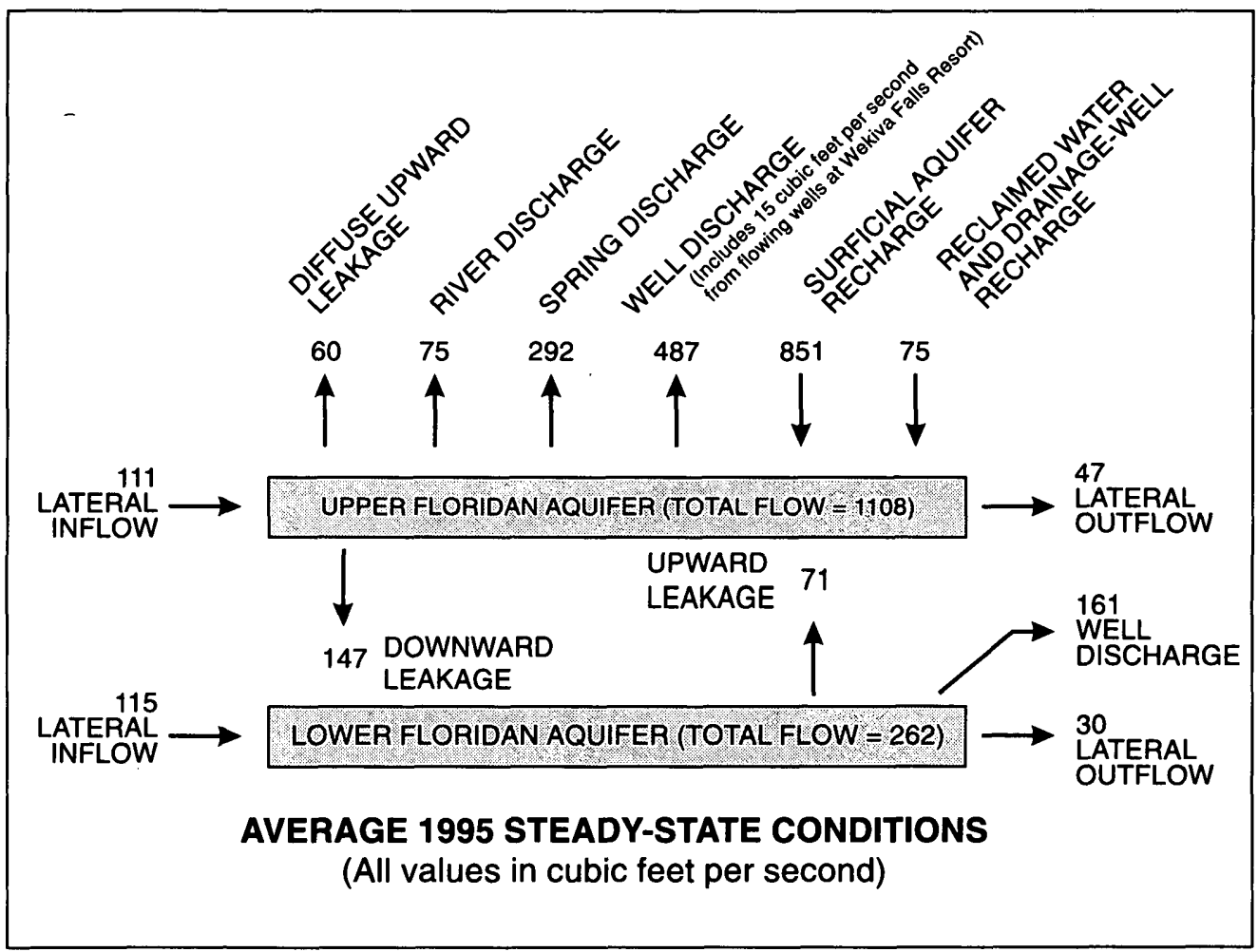

Figure 9. Simulated hydrologic budget for average 1995 steady-state conditions. 
Table 1. Measured and simulated discharge from Upper Floridan aquifer springs for average 1995 conditions and projected 2020 steady-state wet and dry conditions

[Discharge in cubic feet per second. To convert from cubic feet per second to millions of gallons per day, multiply the indicated value by $0.6463 .--$, no measurements made in 1995]

\begin{tabular}{|c|c|c|c|c|c|c|}
\hline \multirow{2}{*}{ Spring } & \multicolumn{2}{|c|}{ Average 1995} & \multicolumn{2}{|c|}{2020 wet } & \multicolumn{2}{|c|}{2020 dry } \\
\hline & Measured $^{\mathrm{a}}$ & Simulated & Simulated & $\begin{array}{l}\text { Percent } \\
\text { change }\end{array}$ & Simulated & $\begin{array}{l}\text { Percent } \\
\text { change }\end{array}$ \\
\hline Wekiva & 68.5 & 67.4 & 61.2 & -9 & 45.0 & -33 \\
\hline Apopka & -- & 55.5 & 53.7 & -3 & 34.8 & -37 \\
\hline Rock & 60.0 & 55.7 & 51.3 & -8 & 41.4 & -26 \\
\hline Sanlando, Palm, and Starbuck & 42.5 & 39.0 & 27.9 & -28 & 9.4 & -76 \\
\hline Seminole & $38.0^{\mathrm{b}}$ & 36.3 & 33.3 & -8 & 22.0 & -45 \\
\hline Messant & 15.5 & 15.5 & 14.8 & -4 & 12.8 & -17 \\
\hline Island & -- & 6.9 & 6.4 & -7 & 5.3 & -22 \\
\hline Gemini & 8.0 & 6.6 & 5.9 & -10 & 4.2 & -36 \\
\hline Miami & 5.8 & 4.7 & 4.1 & -14 & 2.5 & -47 \\
\hline Witherington & -- & 1.0 & .9 & -10 & .6 & -54 \\
\hline Clifton & -- & 1.4 & 1.1 & -19 & .7 & -50 \\
\hline Sulphur & -- & 1.1 & 1.0 & -8 & .7 & -30 \\
\hline Lake Jessup & -- & .8 & .6 & -17 & .4 & -48 \\
\hline Total & 238.3 & $\begin{array}{l}291.9 \\
225.2^{c}\end{array}$ & 262.2 & -10 & 179.8 & -38 \\
\hline
\end{tabular}

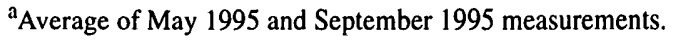

${ }^{b}$ Average of May 1995 and July 1995 measurements.

${ }^{\mathrm{c}}$ Total simulated discharge from the springs measured in 1995.
}

Discharge simulated by the model from Upper Floridan aquifer springs was reduced by 10 percent (from $292 \mathrm{ft}^{3} / \mathrm{s}$ to $262 \mathrm{ft}^{3} / \mathrm{s}$ ) for wet conditions and by 38 percent (from $292 \mathrm{ft}^{3} / \mathrm{s}$ to $180 \mathrm{ft}^{3} / \mathrm{s}$ ) for dry conditions (table 1). Individual spring discharges were all reduced, with the largest reduction ( 28 and 76 percent) simulated at the Sanlando Springs group (Sanlando, Palm, and Starbuck Springs). Discharge from Wekiva and Rock Springs was reduced by 9 and 8 percent, respectively, for wet conditions, and by 33 and 26 percent for dry conditions.

Water levels simulated in the Lower Floridan aquifer for projected 2020 wet conditions (figure 14) are considerably higher than those simulated for dry conditions (figure 15). For dry conditions, computed water-level altitudes fall below 10 feet in several areas of central and southwest Orange County and in one area of east Seminole County. Maximum drawdowns occur at and near large wellfields in southwest Orange County and exceed 20 feet for wet conditions (figure 16) and
45 feet for dry conditions (figure 17). In both cases, simulated drawdowns exceed 5 feet across most of the study area. Differences between the drawdowns simulated for wet and dry 2020 conditions in the Upper and Lower Floridan aquifers are greatest in central and southwest Orange County (figs. 18 and 19).

The water budgets shown in figure 20 quantify the rates of recharge and discharge simulated by the model to, from, and between the Upper and Lower Floridan aquifers for both wet and dry conditions, and the changes relative to 1995 conditions. As shown, increased ground-water withdrawals in 2020 are primarily compensated by increases in recharge from the surficial aquifer system and decreases in springflow. Relative to 2020 wet conditions, the 50 percent increase in ground-water withdrawals specified for dry conditions is compensated by increased recharge from the surficial aquifer system and by reductions in springflow, with smaller decreases in river discharge, diffuse upward leakage, and lateral outflow. 


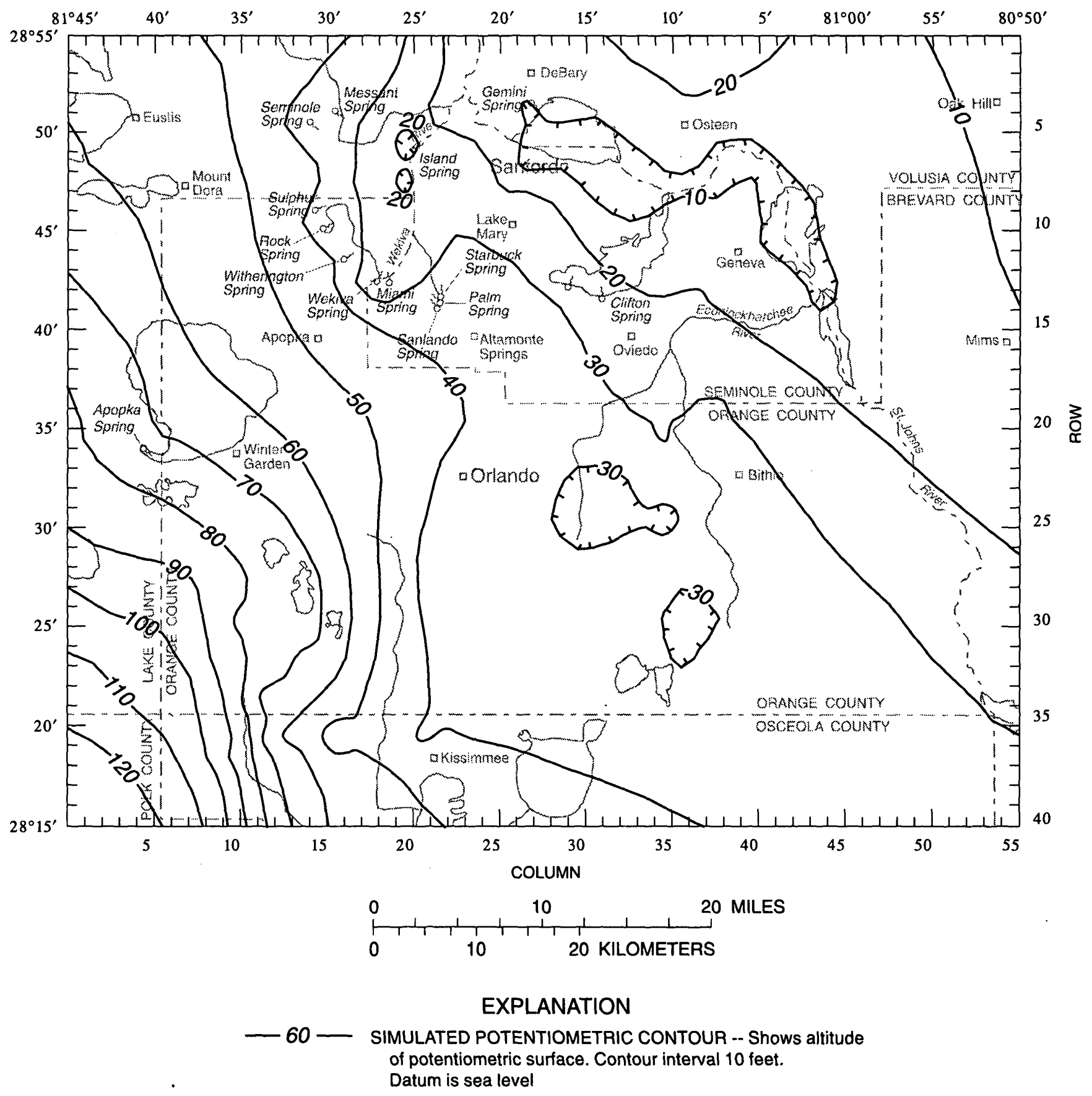

Figure 10. Simulated potentiometric surface of the Upper Floridan aquifer, wet 2020 steady-state conditions. 


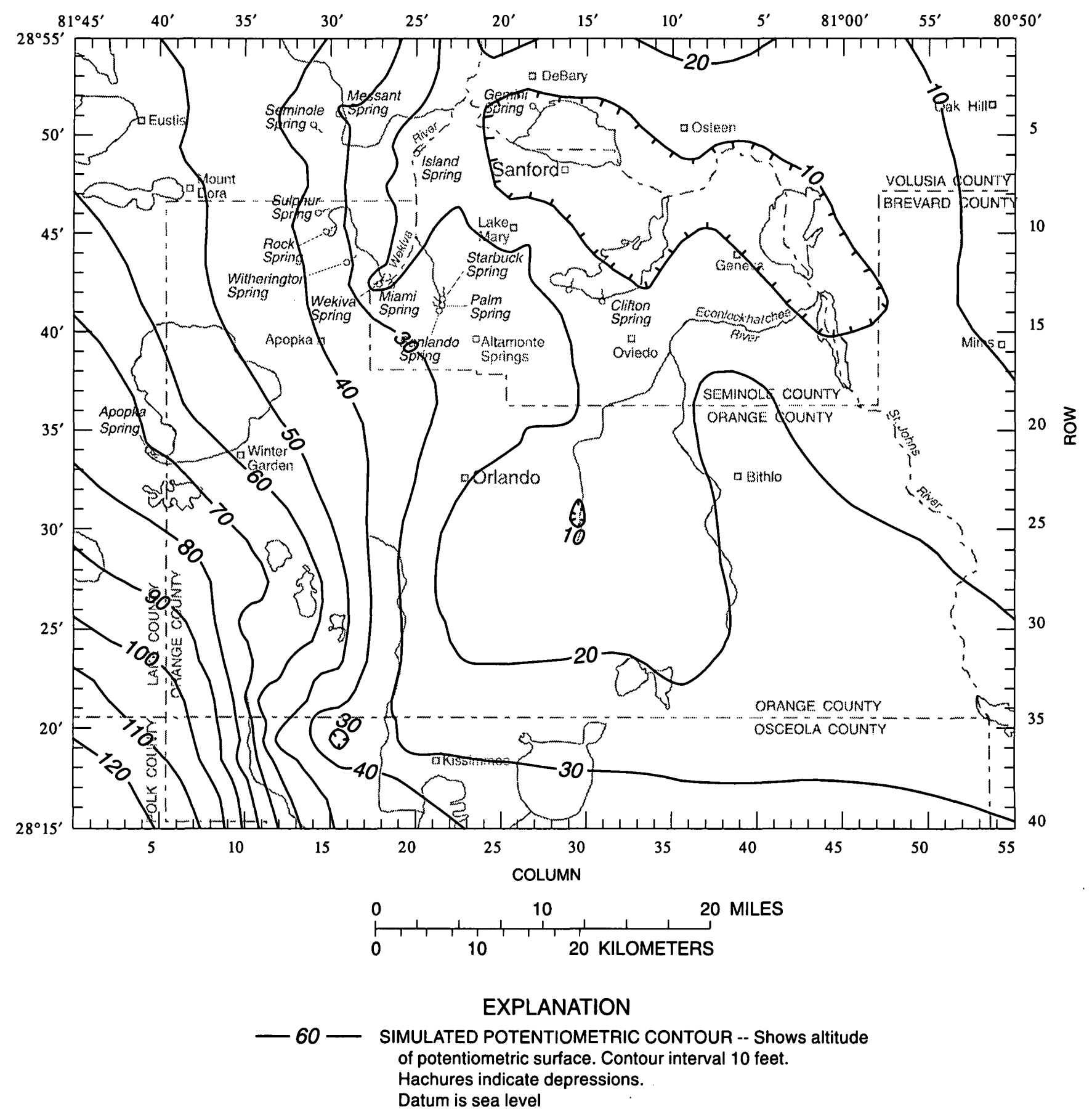

Figure 11. Simulated potentiometric surface of the Upper Floridan aquifer, dry 2020 steady-state conditions. 


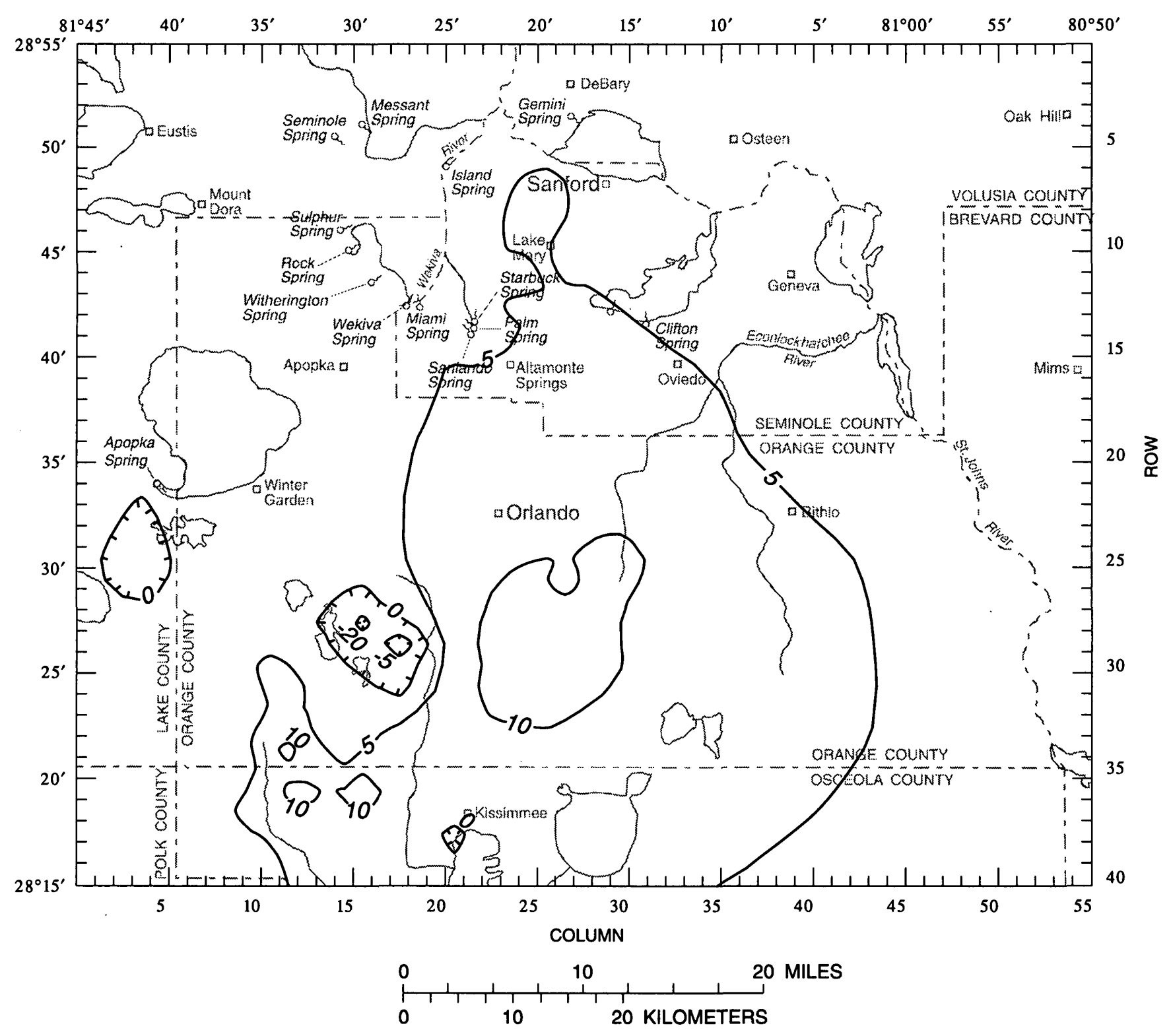

\section{EXPLANATION}

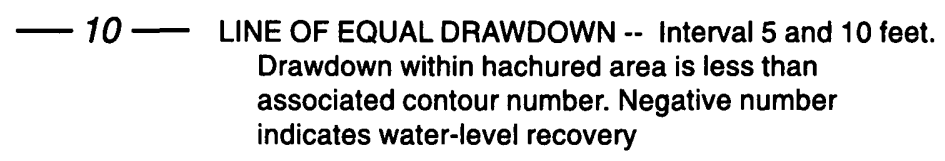

Figure 12. Simulated drawdown in the Upper Floridan aquifer from average 1995 to wet 2020 steady-state conditions. 


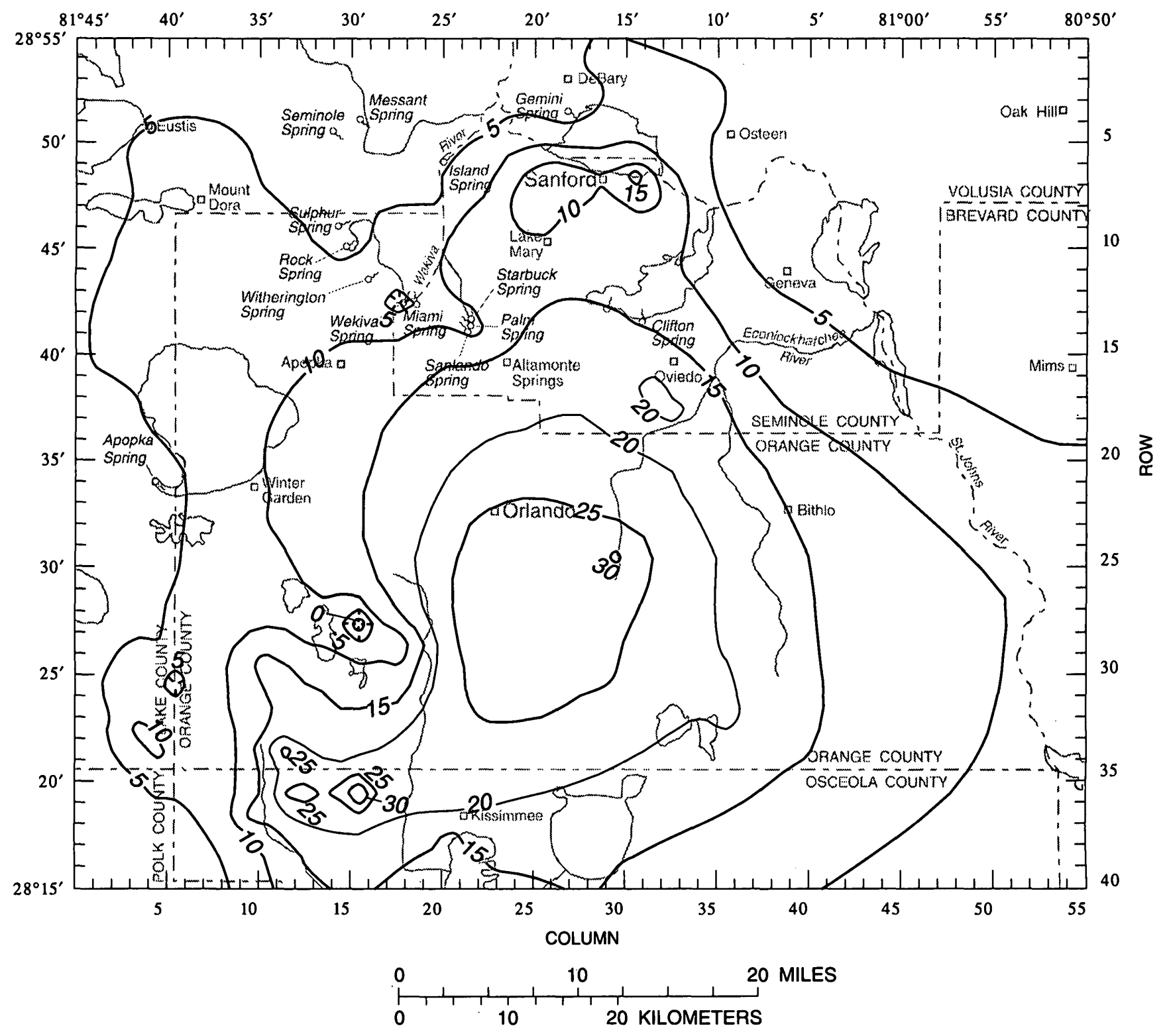

EXPLANATION

- 20 - LINE OF EQUAL DRAWDOWN -- Interval 5 feet.

Drawdown within hachured area is less than

associated contour number

Figure 13. Simulated drawdown in the Upper Floridan aquifer from average 1995 to dry 2020 steady-state conditions. 


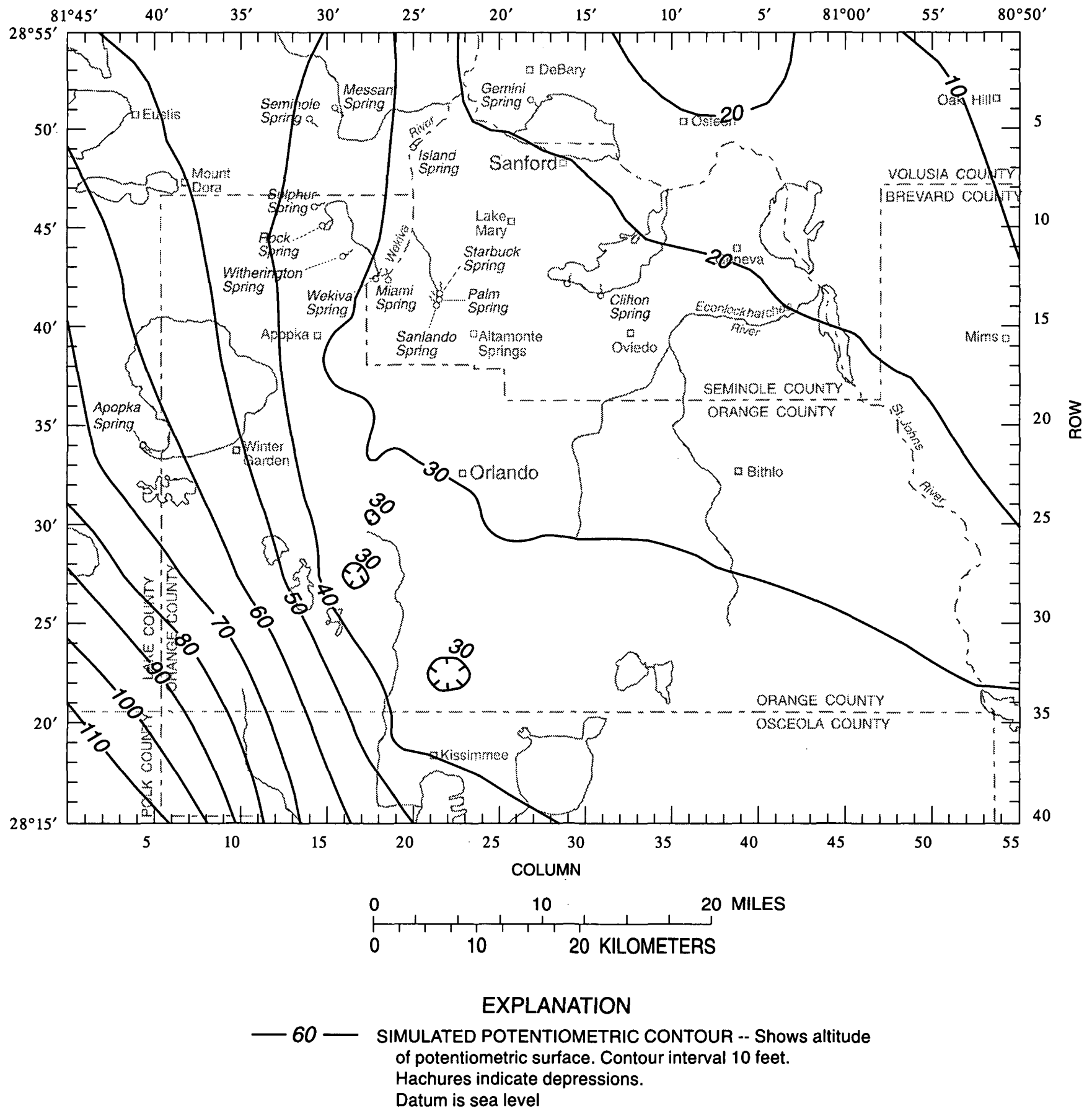

Figure 14. Simulated potentiometric surface of the Lower Floridan aquifer, wet 2020 steady-state conditions. 


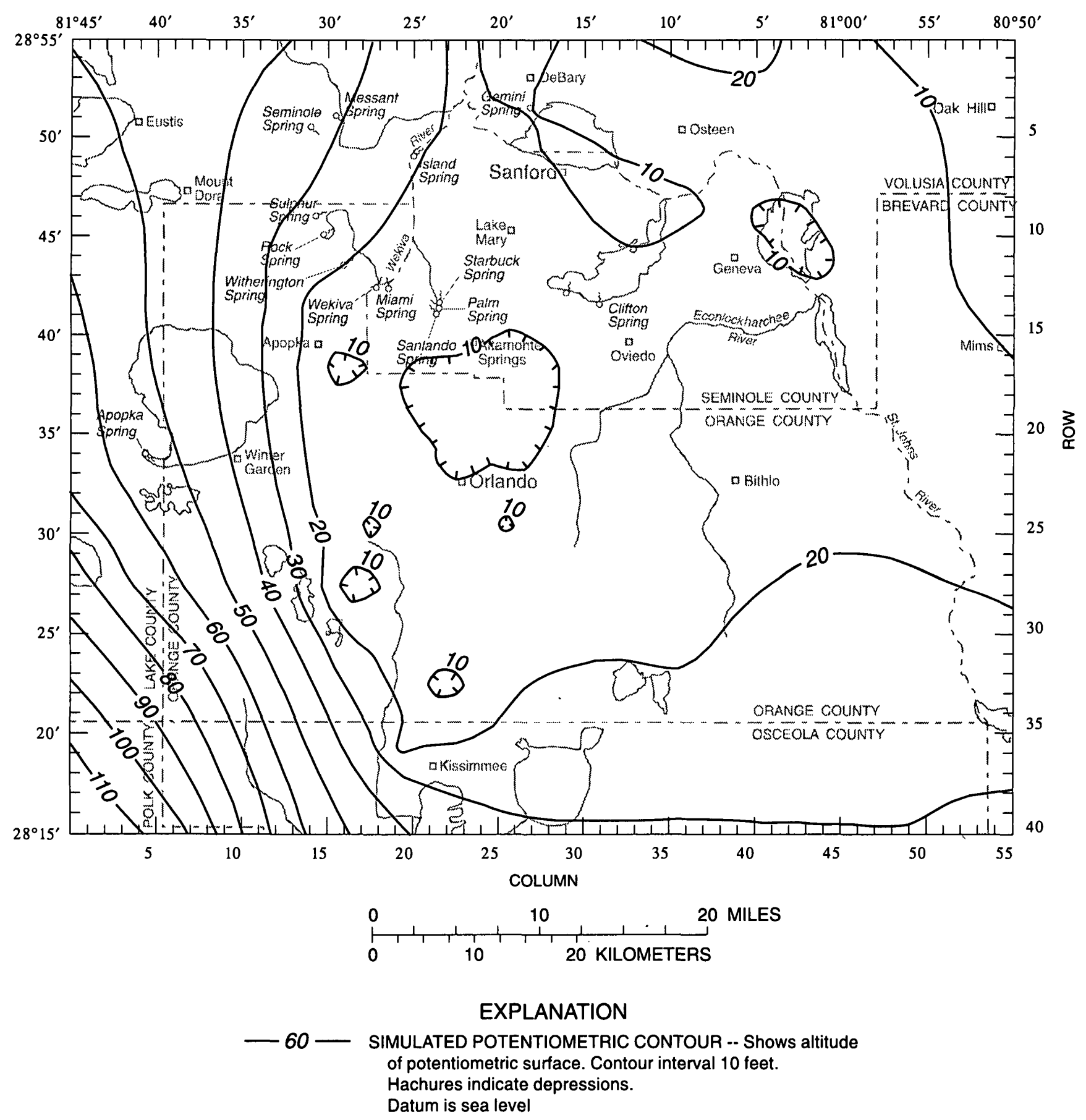

Figure 15. Simulated potentiometric surface of the Lower Floridan aquifer, dry 2020 steady-state conditions. 


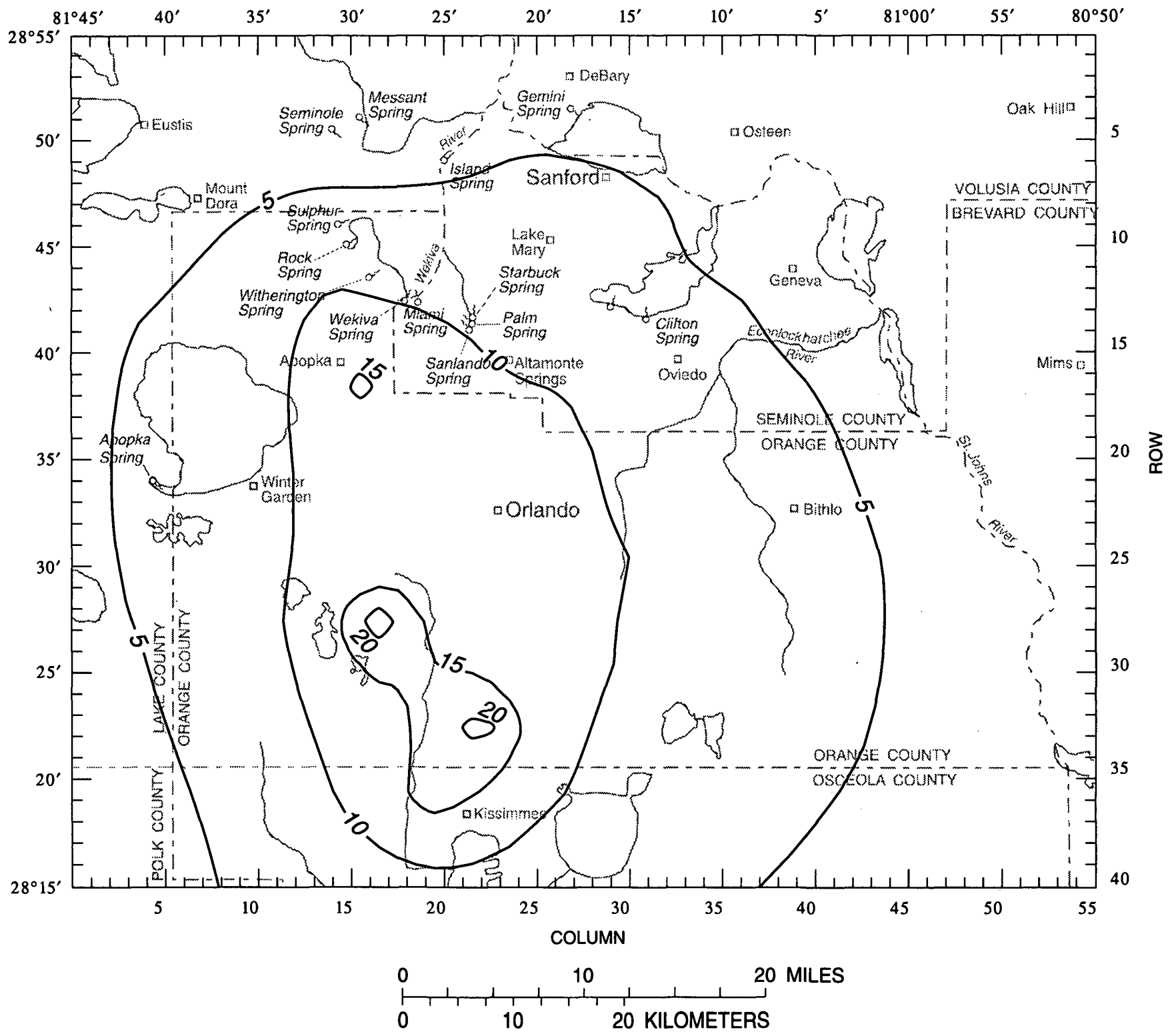

\section{EXPLANATION}

- 15 - LINE OF EQUAL DRAWDOWN -- Interval 5 feet

Figure 16. Simulated drawdown in the Lower Floridan aquifer from average 1995 to wet 2020 steady-state conditions. 


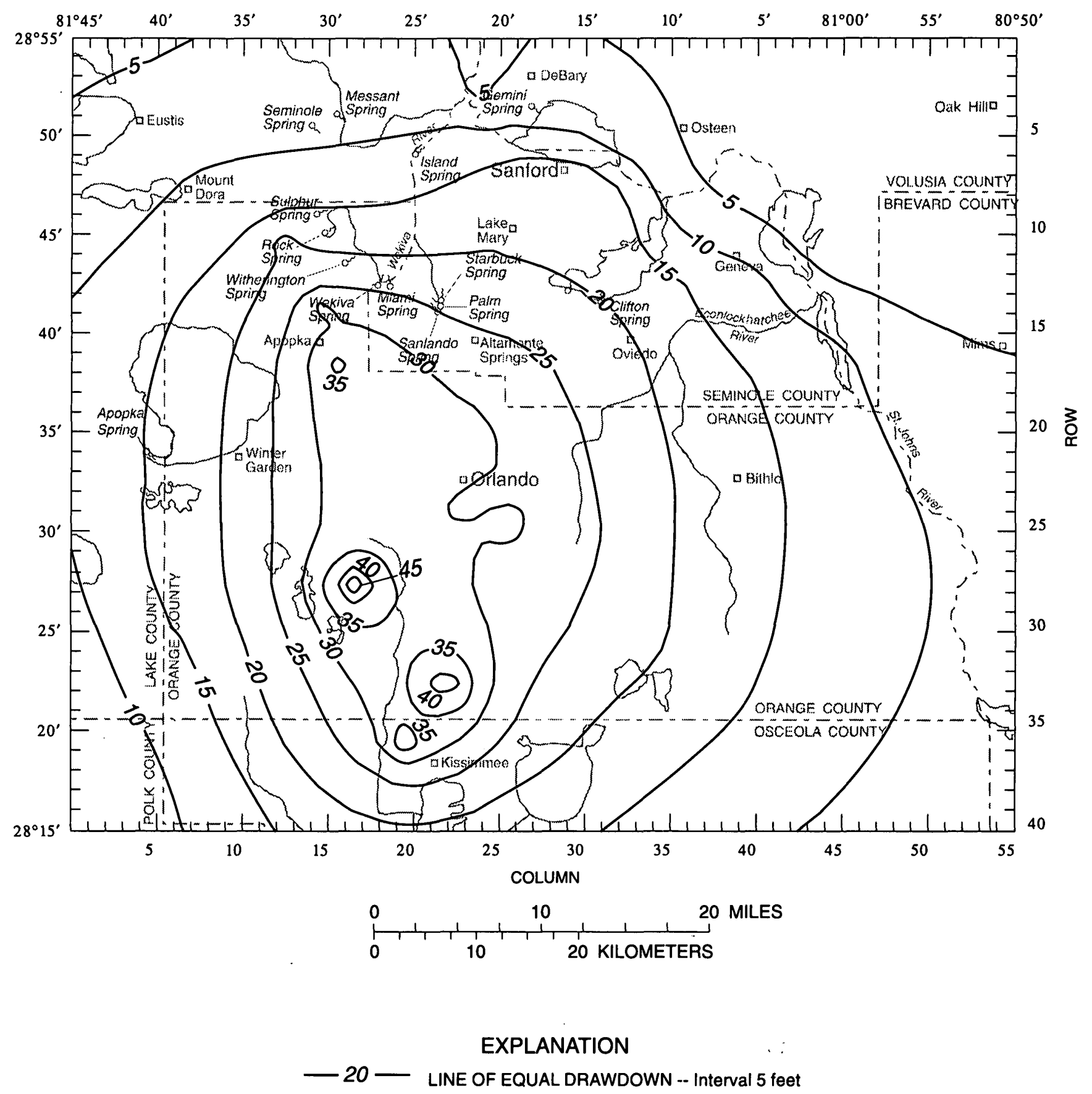

Figure 17. Simulated drawdown in the Lower Floridan aquifer from average 1995 to dry 2020 steady-state conditions. 

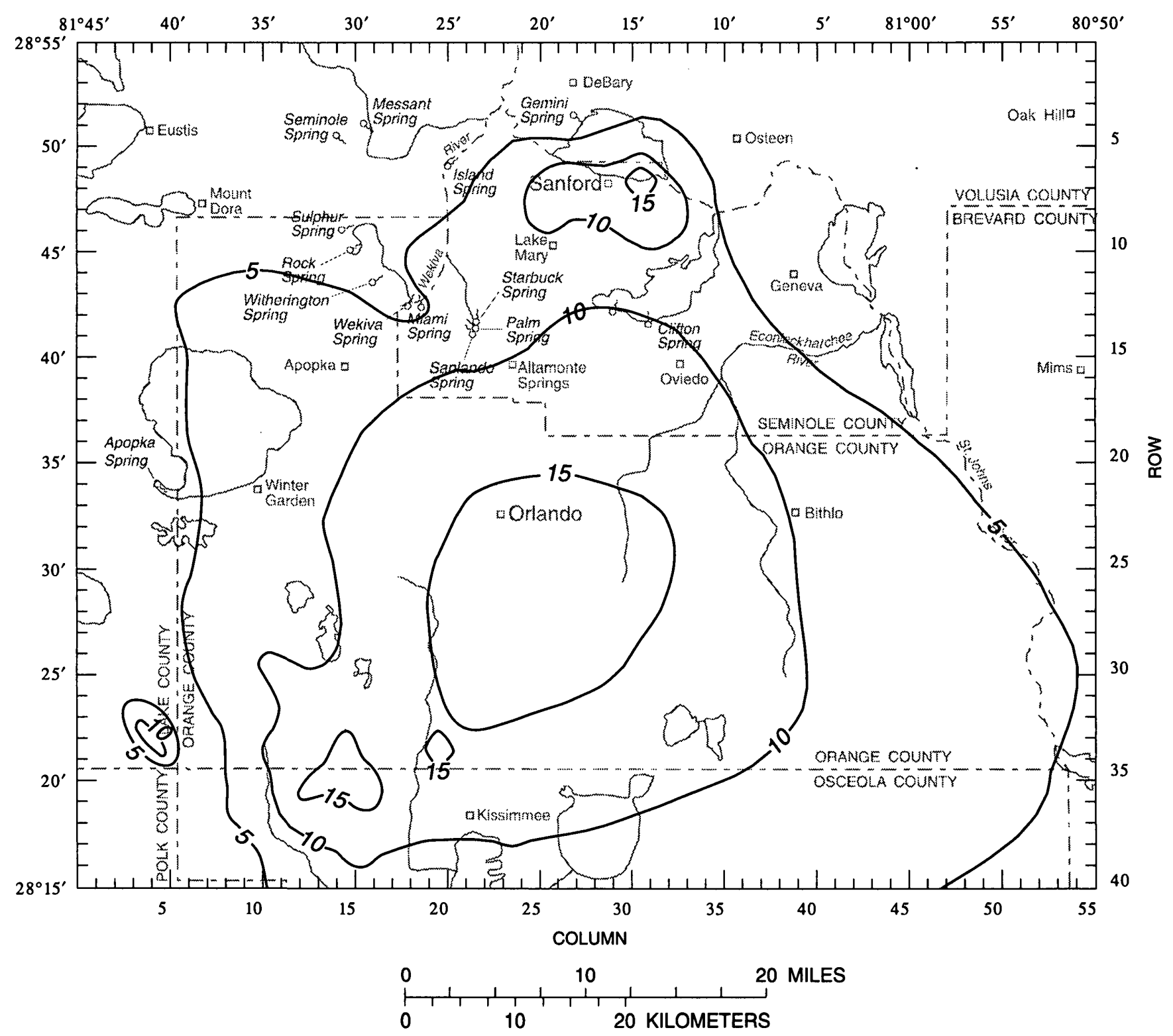

\section{EXPLANATION}

- 10 - LINE OF EQUAL DRAWDOWN DIFFERENCE --

Line shows difference in simulated drawdown between

wet 2020 and dry 2020 conditions. Intervals 5 and 10 feet

Figure 18. Difference in simulated drawdown in the Upper Floridan aquifer from wet 2020 conditions to dry 2020 conditions. 


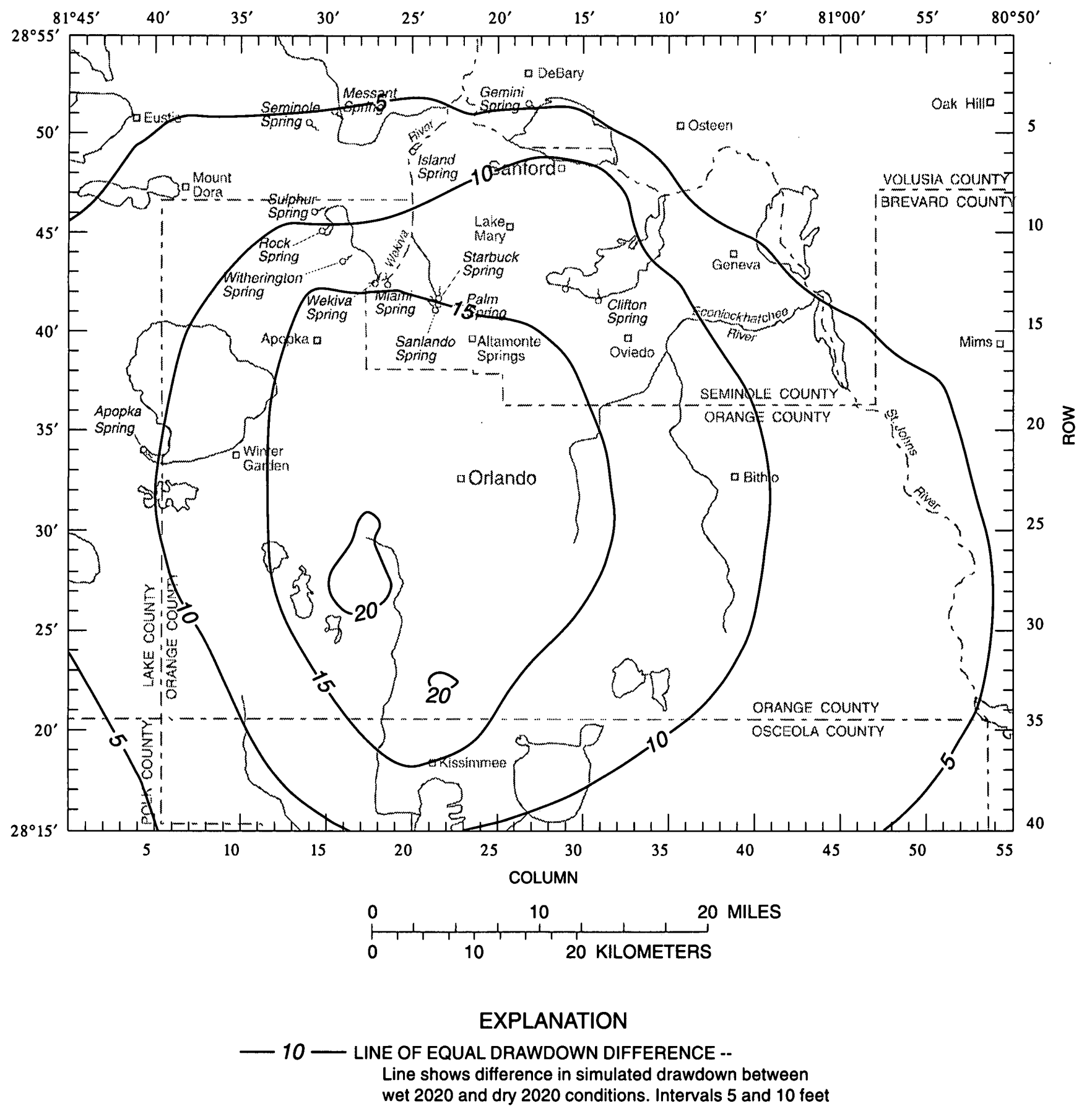

Figure 19. Difference in simulated drawdown in the Lower Floridan aquifer from wet 2020 conditions to dry 2020 conditions. 


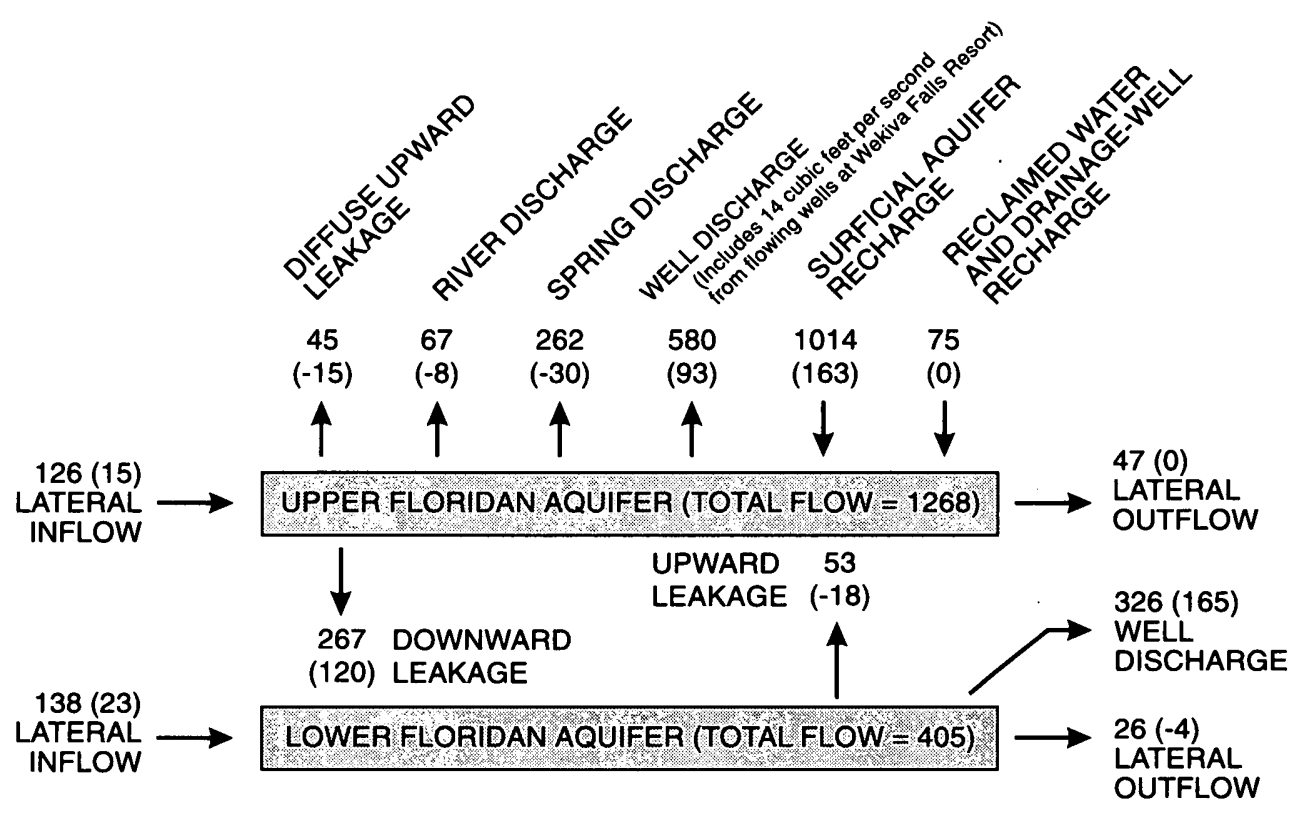

PROJECTED 2020 WET CONDITIONS

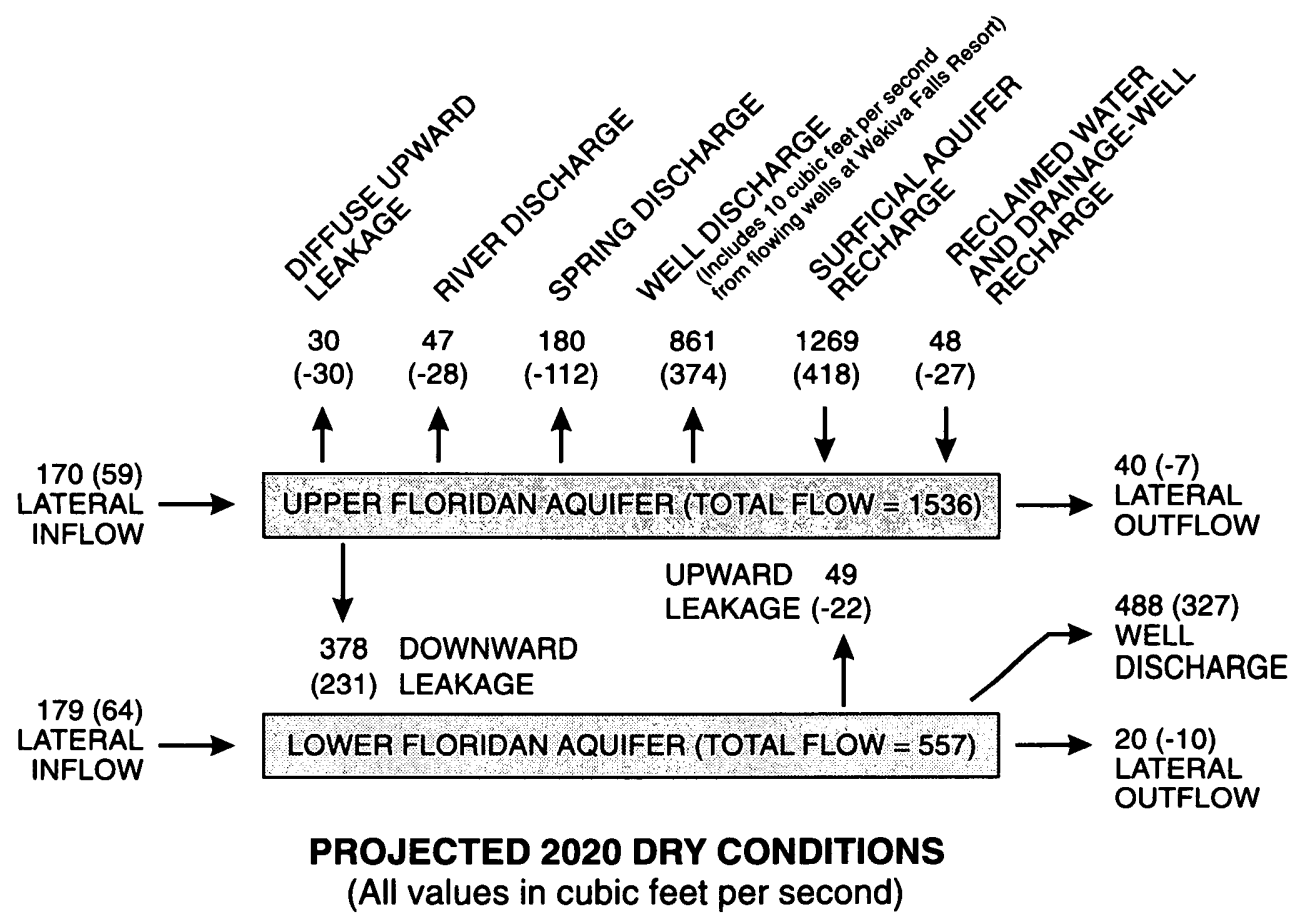

Figure 20. Simulated hydrologic budgets for projected steady-state 2020 wet and dry conditions. 


\section{MODEL LIMITATIONS}

The flow model addressed questions about potential ground-water level declines and springflow decreases within the greater Orlando metropolitan area fairly well, but it cannot mimic the true system exactly. This model is limited by simplification of the conceptual model, uncertainty in the projected pumpage, discretization effects, and difficulty in defining all of the spatial variation in hydraulic properties throughout the model area.

The conceptual model has been simplified by assuming the effects of projected pumpage increases within the greater Orlando metropolitan area can be assessed with a steady-state ground-water flow model. However, available data indicate that between 1980 and 1992, water levels fluctuated seasonally as much as 12 feet in the Floridan aquifer (Murray and Halford, 1996, fig. 11), and the surficial aquifer system infrequently approached a quasi-steady state condition. A steady-state model cannot simulate the projected seasonal variations, but the range of expected waterlevel and springflow changes caused by projected pumpage increases can be simulated.

Average pumpage rates and well locations in 2020 were projected from population estimates. If the population projections for 2020 differ from the estimates used in this study, the projected average pumpage rates and well locations also could differ. Lower water levels and greater spring-discharge reductions would be predicted if pumpage rates are greater than the projections used in this study. Simulated depressions in the potentiometric surfaces of the Upper Floridan and Lower Floridan aquifers would be laterally displaced if projected well locations change.

Lateral discretization of the study area into a rectangular grid of cells and vertical discretization into layers forced an averaging of hydraulic properties. Each cell represents a homogeneous block or some volumetric average of the aquifer medium. Discretization errors occurred because the permeable features of the Floridan aquifer are vugs, voids, and dissolution features that are considerably smaller than the typical volume of a model cell. Due to the averaging of the hydraulic properties, the model cannot simulate local anomalies in the potentiometric surfaces of the Upper Floridan and Lower Floridan aquifers. Simplifying the model to this degree does not invalidate the model results, but does mean that model results should be interpreted at scales larger than the representative elemental volume of hydraulic conductivity.
Finally, the results discussed in this report were bracketed to address boundary condition constraints. The wet and dry extremes referenced in this report probably bracket the effects that may occur in 2020 for the given pumpage rates and distribution, with average rainfall conditions. However, it was beyond the scope of this study to quantify the statistical occurrence of the deficit or excess rainfall conditions associated with the bracketed results.

\section{SUMMARY}

The greater Orlando metropolitan area encompasses about 2,500 square miles and includes all of Orange and Seminole Counties, and parts of adjacent Lake, Volusia, Brevard, Osceola, and Polk Counties. Virtually all of the water used to meet municipal, industrial, and agricultural demands is obtained from the underlying Floridan aquifer system. This system is composed of two highly-productive zones, the Upper and Lower Floridan aquifers, separated by the less permeable middle semiconfining unit. The Floridan aquifer system is recharged primarily by leakage from the overlying surficial aquifer system and is discharged by wells and springs.

The USGS has described the hydrogeologic conditions in the greater Orlando metropolitan area and documented the construction and calibration of a computer model (the Metro model) used to simulate 1988 steady-state and transient 1990 flow conditions in the area. In 1997, the USGS began a study using the Metro model to assess the potential effects of estimated 2020 ground-water withdrawals $(576 \mathrm{Mgal} / \mathrm{d}$ or $891 \mathrm{ft}^{3} / \mathrm{s}$ ) on water levels and springflow in the Floridan aquifer system. Results were compared to those simulated for 1995 steady-state conditions and were bracketed to estimate a range of potential effects. Drawdowns simulated for 2020 wet conditions, which used the 1988 fixed-head and recharge arrays described by Murray and Halford (1996), probably are smaller than those that can be expected to occur in 2020 under average rainfall conditions and for the given pumpage rates and distributions.

Drawdowns simulated for 2020 dry conditions, which were based on the drought-induced May 1990 fixed-head and recharge arrays and a 50 percent increase in distributed pumpage, probably are greater than those that would be expected in 2020. Also, the discharge rates simulated at the Upper Floridan aquifer springs for wet conditions probably are higher than 
those that can be expected in 2020 , while those simulated for dry conditions probably are lower than would be expected.

Water levels and springflow simulated by the model for 1995 steady-state conditions were reasonably close to measured values, except in an area of north Seminole County where the discharge rate from abandoned flowing wells estimated by SJRWMD was greater than that originally used to calibrate the Metro model. Drawdowns simulated in the Upper Floridan aquifer exceeded 10 and 25 feet for wet and dry conditions, respectively, in parts of central and southwest Orange County and in north Osceola County. In Seminole County, drawdowns of up to 20 feet are simulated for dry conditions, compared with 5 to 10 feet simulated for wet conditions. In the Lower Floridan aquifer, drawdowns simulated in southwest Orange County exceeded 20 and 40 feet for wet and dry conditions, respectively. Simulated springflow was reduced by 10 percent, from $292 \mathrm{ft}^{3} / \mathrm{s}(189 \mathrm{Mgal} / \mathrm{d})$ in 1995 to $262 \mathrm{ft}^{3} / \mathrm{s}(170 \mathrm{Mgal} / \mathrm{d})$ in 2020 , for wet conditions and by 38 percent (from $292 \mathrm{ft}^{3} / \mathrm{s}(189 \mathrm{Mgal} / \mathrm{d}$ ) to $\left.180 \mathrm{ft}^{3} / \mathrm{s}(116 \mathrm{Mgal} / \mathrm{d})\right)$ for dry conditions. The largest reductions (28 and 76 percent) occur at the Sanlando Springs group.

\section{REFERENCES}

Knowles, L., Jr., O’Reilly, A.M., Phelps, G.G., and Bradner, L.A., 1995, Potentiometric surface of the Upper Floridan aquifer in the St. Johns River Water Management District and vicinity, Florida, May 1995: U.S. Geological Survey Open-File Report 95-461, 1 sheet.

McDonald, M.G., and Harbaugh, A.W., 1988, A modular three-dimensional finite-difference ground-water flow model: U.S. Geological Survey Techniques of WaterResources Investigations, book 6, chap. A1, 576 p.

Murray, L.C., Jr., and Halford, K.J., 1996, Hydrogeologic conditions and simulation of ground-water flow in the greater Orlando metropolitan area, east-central Florida: U.S. Geological Survey Water-Resources Investigations Report 96-4181, 100 p.

O'Reilly, A.M., Bradner, L.A., Knowles, L., Jr., and Phelps, G.G., 1996, Potentiometric surface of the Upper Floridan aquifer in the St. Johns River Water Management District and vicinity, Florida, September 1995: U.S. Geological Survey Open-File Report 96-131, 1 sheet.

Tibbals, C.H., 1990, Hydrology of the Floridan aquifer system in east-central Florida: U.S. Geological Survey Professional Paper 1403-E, 98 p. 
U.S. Department of the Interior

U.S. Geological Survey

227 North Bronough Street

Suite 3015

Tallahassee, FL 32301-1372

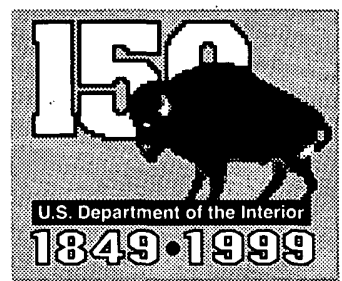

49 Printed on recycled paper 